\title{
A INCRÍVEL DOUTRINA DE UM CASO SÓ: ANÁLISE DO ESTADO DE COISAS INCONSTITUCIONAL NA ADPF 347
}

\author{
THE INCREDIBLE SINGLE CASE DOCTRINE: ANALYSIS OF THE STATE OF \\ UNCONSTITUTIONAL AFFAIRS IN ADPF 347
}

\section{LA INCRIBLE DOCTRINA DE UN CASO SOLO: ANÁLISIS DEL ESTADO DE COSAS INCONSTITUCIONAL EN ADPF 347}

\author{
BRENo Baía MAGALHÃES \\ https://orcid.org/0000-0002-7183-2440 / http://lattes.cnpq.br/0126393188779750 / brenobaiamag@gmail.com \\ Universidade Federal do Pará. \\ Belém, PA, Brasil.
}

\begin{abstract}
RESUMO
O artigo pretende realizar uma análise dogmática da ADPF 347, precedente que inseriu a categoria Estado de Coisas Inconstitucional (ECI) no cânone interpretativo do Direito Constitucional brasileiro. A criação da categoria implica na delimitação de seus elementos para sua caracterização e aplicação em casos posteriores. Dessa forma, como método, o artigo pretende realizar uma análise dogmática dos elementos que perfazem a identificação de um $\mathrm{ECl}$, de acordo com a decisão tomada pelo Supremo Tribunal Federal (STF). O estudo dogmático partiu de uma descrição de seus contornos constitucionais, ou seja, dos requisitos para a declaração do ECl e suas características, para, em seguida, contestar a caracterização constitucional da categoria em análise e realçar a mobilização dos ministros do STF no sentido de limitar sua aplicabilidade apenas ao caso do sistema carcerário. 0 estudo conclui que as categorias dogmáticas são problemáticas do ponto de vista de sua coerência argumentativa e sua aplicação se restringirá ao caso do sistema carcerário brasileiro.
\end{abstract}

Palavras-chave: Estado de Coisas Inconstitucional; Hipóteses de Cabimento; Supremo Tribunal Federal.

\begin{abstract}
The article intends to make a dogmatic analysis of ADPF 347, a judicial precedent that inserted the category State of Unconstitutional Affairs (SUA) in the interpretative canon of the Brazilian Constitutional Law. The creation of said category implies the delimitation of its elements for their characterization and application in later cases. Thus, as a scientific method, the article intends to perform a dogmatic analysis of the elements that make up the identification of an SUA, according to the decision taken by the Federal Supreme Court (FSC). The dogmatic study proceeded from a description of its constitutional contours, that is, the requirements for the declaration of the $\mathrm{ECl}$ and its characteristics, to then challenge the constitutional characterization of the category under consideration and to highlight the mobilization of the FSC justices in order to limit its applicability only to the case of the prison system. The study concludes that the dogmatic categorie is problematic from the point of view of its argumentative coherence and its application will be restricted to the case of the Brazilian prison system.
\end{abstract}

Keywords: State of Unconstitutional Affairs; Fitting Hypotheses; Supreme Federal Court.

\section{RESUMEN}

El artículo pretende hacer un análisis dogmático de ADPF 347, precedente que inserta la categoría Estado de cosas inconstitucional $(\mathrm{ECl})$ en el canon interpretativo del Derecho Constitucional brasileño. La creación de la categoría implica la delimitación de sus elementos para su caracterización y aplicación en casos posteriores. Por lo tanto, como método, el artículo pretende realizar un análisis dogmático de los elementos que componen la identificación de un $\mathrm{ECl}$, de acuerdo con la decisión tomada por el Tribunal Supremo Federal (TSF). El estudio dogmático procedió de una 
descripción de sus contornos constitucionales, es decir, los requisitos para la declaración de la $\mathrm{ECl}$ y sus características, para luego desafiar la caracterización constitucional de la categoría en consideración y destacar la movilización de los ministros del STF para limitar su aplicabilidad solo al caso del sistema penitenciario. El estudio concluye que las categorías dogmáticas son problemáticas desde el punto de vista de su coherencia argumentativa y su aplicación se limitará al caso del sistema penitenciario brasileño.

Palabras clave: Estado de Cosas Inconstitucionales; Hipótesis de Cabimiento; Supremo Tribunal Federal.

\section{SUMÁRIO}

INTRODUÇÃO; 1 O JULGAMENTO DA MC NA ADPF 347; 2 CRÍTICAS À CARACTERIZAÇÃO DOGMÁTICA DO ECI NO BRASIL; 3 REVISÃO DOS PRESSUPOSTOS DE CABIMENTO DO ECI BRASILEIRO; CONCLUSÃO; REFERÊNCIAS.

\section{INTRODUÇÃO}

Em setembro de 2015, o Supremo Tribunal Federal (STF) reconheceu um Estado de Coisas Inconstitucional (ECI) no sistema carcerário brasileiro, ocasionado por violações generalizadas de direitos fundamentais e reiterada inércia estatal. A decretação de tal estado de coisas implicaria na determinação de medidas estruturais flexíveis a serem manejadas e monitoradas pela corte, com o auxílio dos demais poderes, órgãos e pessoas afetadas. ${ }^{1}$

Passados quase quatro anos de sua decretação, pouco ou nada mudou na realidade dos milhares de detentos submetidos, diariamente, a condições desumanas de encarceramento ${ }^{2}$.

\footnotetext{
${ }^{1}$ No mérito, o autor da Arguição de Descumprimento de Preceito Fundamental (ADPF) requeria, entre outros pedidos: a) que fossem determinados ao Governo Federal a elaboração e o encaminhamento ao Supremo, no prazo de três meses, de um plano nacional visando à superação, dentro de três anos, do quadro dramático do sistema penitenciário brasileiro; b) que o aludido plano contivesse propostas e metas; c) que o plano previsse os recursos necessários à implementação das propostas e o cronograma para a efetivação das medidas; d) que o plano fosse submetido à análise do Conselho Nacional de Justiça (CNJ), da Procuradoria-Geral da República (PGR), da Defensoria-Geral da União, do Conselho Federal da Ordem dos Advogados do Brasil (CFOAB), do Conselho Nacional do Ministério Público (CNMP) e de outros órgãos e instituições que desejassem se manifestar e da sociedade civil; e) que o Tribunal deliberasse sobre o plano, para homologá-lo ou impor providências alternativas ou complementares; f) uma vez homologado o plano, fosse determinado aos governos dos estados e do Distrito Federal que formulassem e apresentassem ao Supremo, em três meses, planos próprios em harmonia com o nacional, contendo metas e propostas específicas para a superação do $\mathrm{ECl}$; g) que o Tribunal deliberasse sobre cada plano estadual e distrital, para homologá-los ou impor providências alternativas ou complementares; e h) que o Supremo monitorasse a implementação dos planos nacional, estaduais e distrital, com o auxílio do Departamento de Monitoramento e Fiscalização do Sistema Carcerário (DMF) e do Sistema de Execução de Medidas Socioeducativas do $\mathrm{CNJ}$, em processo público e transparente, aberto à participação colaborativa da sociedade civil.

20 presente artigo representa a primeira parte de um estudo mais amplo sobre o tema do Estado de Coisas Inconstitucional. Portanto, ambos compartilham uma parte introdutória semelhante. Em outro artigo, expusemos a suposta eficácia e o exato impacto provocado pela decisão na situação carcerária. Cf. MAGALHÃES, Breno Baía. O Estado de Coisas Inconstitucional na ADPF 347 e a sedução do Direito: o
} 
Muito embora tenha sido saudada como importação bem-vinda por alguns autores ${ }^{3}$, outros não pouparam críticas ${ }^{4}$ ao instituto do $\mathrm{ECl}$ no direito brasileiro. A maioria desses debates, contudo, manteve-se no âmbito opinativo das manifestações jornalísticas e ainda não se estendeu de forma profunda na academia, especialmente no que diz respeito à exploração de seus contornos dogmáticos.

A tendência dos estudos feitos no campo acadêmico sobre o $\mathrm{ECl}$ é a de não problematizar sua feição enquanto categoria dogmática constitucional, com trabalhos que: a) se limitam em reproduzir o decidido pelo $\mathrm{STF}^{5}$; b) sugerem sua inserção na decantada e pouco produtiva discussão sobre ativismo judicial ${ }^{6}$; c) propõem sua extensão e aplicação para outros direitos fundamentais ou situações tidas como problemáticas $^{7}$ ou d) apenas reforçam e reafirmam a importância do $\mathrm{ECl}$ no atual cenário social ${ }^{8}$.

impacto da medida cautelar e a resposta dos poderes políticos. REVISTA DIREITO GV (ONLINE), v. 15, p. 1 37, 2019.

${ }^{3}$ CAMPOS, Carlos Alexandre de Azevedo. Jota Mundo: Estado de Coisas Inconstitucional. Artigo publicado in: http://jota.info/jotamundo-estado-de-coisas-inconstitucional e RODRIGUEZ, José Rodrigo. Estado de coisas surreal. Disponível em: https://jota.info/artigos/estado-de-coisas-surreal-25092015. Acesso em: 26 set. 2017.

${ }^{4}$ STRECK, Lenio Luiz. Estado de coisas inconstitucional é uma nova forma de ativismo [online]. In: Revista Consultor Jurídico, 24 de outubro de 2015, GLEZER, Rubens; MACHADO, Eloísa. Decide, mas não muda: STF e o Estado de Coisas Inconstitucional [online]. In: JOTA. Publicado em 9 de setembro de 2015 e DE GIORGI, Raffaele; FARIA, José Eduardo; CAMPILONGO, Celso. Estado de Coisas Inconstitucional. Artigo publicado in: Estadão em 19 de Setembro de 2015.

${ }^{5}$ SANTOS et. al. Estado de Coisas Inconstitucional: Um Estudo Sobre os Casos Colombiano e Brasileiro. Quaestio luris, vol. 08, $n^{\circ}$. 04, 2015, p. 2.596-2.612; CALDAS, Roberto Correia da Silva Gomes; NETO, Felipe Lascane. As condições das penitenciárias no brasil e o estado de coisas inconstitucional. Revista de Direito Penal, Processo Penal e Constituição v. 2, n. 2, p. 578 - 600, 2016; ANDRADE, Bruno Araújo de; TEIXEIRA, Maria Cristina. O Estado de Coisas Inconstitucional - Uma Análise da ADPF 347. Revista do Curso de Direito da Faculdade de Humanidades e Direito, v. 13, n. 13, 2016, p. 85-121 e PEREIRA, Luciano Meneguetti. O Estado de Coisas Inconstitucional e a violação dos direitos humanos no sistema prisional brasileiro. RIDH, v. 5, n. 1, p. 167-190, 2017.

${ }^{6}$ BERNARDI, Renato; MEDA, Ana Paula. Da Tripartição de Poderes ao Estado de Coisas Inconstitucional e o “Compromisso Significativo: A contemporânea atuação do Poder Judiciário na solução de conflitos que envolvem direitos sociais fundamentais. EM TEMPO, vol. 15, p. 11-34, 2016 e PENNA, Bernardo Schmidt. Mais do ativismo judicial à brasileira: análise do estado de coisas inconstitucional e da decisão na ADPF 347. Revista Pensamento Jurídico. Vol. 11, $n^{\circ} 1$, 2017, p. 09-19.

7 Meda e Bernardi (direito à moradia) e OLIVEIRA, Vitor Costa. Estado de coisas inconstitucional no direito fundamental à comunicação: análise do regime jurídico da radiodifusão audiovisual no Brasil. 2016. 121 f. Dissertação (Pós-Graduação em Direito) - Universidade Federal de Sergipe, São Cristóvão, 2016 (direito à liberdade nas comunicações).

${ }^{8}$ DANTAS, Eduardo Sousa. Ações estruturais, direitos fundamentais e o estado de coisas inconstitucional. Revista constituição e garantia de direitos. Vol. 09, n. 02, 2016, p. 155-176; CARVALHO, Gustavo Ferreira de; OLIVEIRA, Fábio de Souza, SANTOS, Júlio Edstron S. O estado de coisas inconstitucional: é possível sua efetivação no Brasil? Revista Acadêmica Conecta FASF. Vol. 2, n 1, p.307-332, 2017 e DUARTE, Júlia Karolline Vieira; NETO, Júlio Gomes Duarte. O estado de coisas inconstitucional $(\mathrm{ECI})$ : o remédio estrutural para a efetivação dos direitos fundamentais perante um diálogo entre os poderes da união. Revista da ESMAL, n.1, p. 298-321, 2016. 
0 traço comum de todos esses trabalhos é o fato de que nenhum problematiza os critérios desenvolvidos pelo tribunal para a decretação de tão importante doutrina, seja no âmbito de sua consistência interna (individualmente considerados) ou de sua coerência quando analisados em conjunto. Dessa forma, é possível identificar um ponto importante para a investigação científica, qual seja o desenvolvimento substancial sobre a construção dogmática do $\mathrm{ECl}$ para a realidade brasileira, a partir dos critérios elencados pelo STF.

Tomado de empréstimo da Corte Constitucional Colombiana (CCC), o ECI não representou a tábua de salvação para os problemas estruturais daquele país, além de contar com importantes opositores no campo acadêmico e ter falhado na prática, dado os tímidos resultados observados (embora simbolicamente significativos no caso dos deslocados internos ${ }^{9}$ ). No campo da superlotação carcerária, por exemplo, o instrumento fracassou espetacularmente.

A utilização de uma doutrina ${ }^{10}$ que pretende inserir medidas estruturais para alterar um estado fático criado por uma complexa mistura de fatores suscita válidas objeções no campo da separação de poderes, em função de uma possível intromissão do Judiciário em assuntos, supostamente, exclusivos do Executivo e do Legislativo. Contudo, não se pretende voltar a essa questão, ou de como o $\mathrm{ECl}$ se desenvolveu na Colômbia, mas sim à feição atribuída ao $\mathrm{ECl}$ pelo STF, bem como questionar a possibilidade daquela doutrina cumprir com suas promessas, partindo de seus pressupostos de cabimento e perfil dogmático.

Dessa forma, este artigo pretende realizar uma análise dogmática de um precedente da corte suprema, partindo de uma descrição de seus contornos constitucionais (requisitos para a declaração do $\mathrm{ECl}$ e suas características) para, em seguida, contestar a caracterização constitucional do ECl e realçar a mobilização dos ministros do STF no sentido de limitar a aplicabilidade do instituto apenas ao caso do sistema carcerário.

\footnotetext{
${ }^{9} \mathrm{O} \mathrm{ECl}$ declarado na sentença da CCC T - 025/04 não foi suficiente para dar cabo do grave problema dos deslocados internos por conta de conflitos internos armados, muito embora tenha servido para que as autoridades públicas dessem mais atenção à grave situação. Por essa razão, adjetivamos sua existência como simbolicamente significativa, mas de pouca consequência prática. RODRÍGUEZ-GARAVITO, César. ¿Cuándo cesa el estado de cosas inconstitucional del desplazamiento? Más allá del desplazamiento, o cómo superar un estado de cosas inconstitucional. In: Más allá del desplazamiento: políticas, derechos y superación del desplazamiento forzado en Colombia. coordinador César Rodríguez Garavito; Juan Carlos Guataquí. et al. Bogotá: Universidad de los Andes, Facultad de Derecho, Ediciones Uniandes, 2009, p. 434494.

10 Uma doutrina pode ser uma moldura de julgamento, um conjunto de regras, etapas procedimentais a serem seguidas pela corte ou testes a serem empregados para revisar uma lei ou política pública, muitas vezes estabelecida por meio de um precedente. Uma doutrina surge quando uma corte estrutura uma moldura decisória e a aplica em casos semelhantes. TILLER, Emerson H.; CROSS, Frank B. What is legal doctrine? Northwestern University Law Review, v.100, n.1, p. 517-533, 2006, p. 518. A nota explicativa se justifica para distanciar-se do conceito corrente no direito brasileiro de "doutrina".
} 
A metodologia empregada é a dogmática, ou seja, parte-se de um conjunto de raciocínios destinados a organizar, sistematicamente, com a utilização de conceitos, institutos e princípios jurídicos, as leis e/ou as decisões do STF, tendo em vista alcançar soluções para casos concretos $^{11}$. Em razão de sua importância, a construção dogmática é, também, uma linguagem de poder, uma vez que circunscreve procedimentos que conduzem uma autoridade judicial à tomada de decisões constitucionais ${ }^{12}$.

Dentro da racionalidade dogmática, sua função sistematizadora delimita o campo de significados a serem empregados no momento da solução de casos concretos, muito embora aqueles significados não estejam definitivamente determinados - serão expandidos ou retraídos na medida em que as demandas legislativas, sociais e judiciais se imponham ${ }^{13}$. A dogmática servirá como uma importante via de controlar, racionalmente, o poder de aplicação do texto constitucional ao estabelecer critérios e conceitos limitadores da mobilidade interpretativa dos tribunais que concretizam a Constituição. A força da dogmática, portanto, imporá ao intérprete a obediência a uma formalização para que sua decisão seja vista como legítima, para fins de controle democrático ${ }^{14}$.

Dessa forma, os argumentos jurídicos decorrentes dos votos dos ministros na Arguição de Descumprimento de Preceito Fundamental (ADPF) $\mathrm{n}^{\circ} 347$ são os dados coletados para a realização de uma análise dogmática, ou seja, para a formulação e crítica do conceito de ECI para fins de averiguação de sua consistência e aplicabilidade posterior em outros casos concretos. Portanto, o conceito de ECI desenvolvido pelo STF é estruturado e seu contorno dogmático criticado e questionado quanto à sua capacidade de servir de precedente aplicável para outros problemas estruturais brasileiros.

11 RODRIGUEZ, J. R. Dogmática é conflito: a racionalidade jurídica entre sistema e problema. In: José Rodrigo Rodriguez; Flávia Portella Püschel, Marta Rodriguez Assis Machado. (Org.). Dogmática é conflito: uma visão crítica da racionalidade jurídica. 1ed.São Paulo: Saraiva, 2012, p. 21.

12 RODRIGUEZ, J. R.; PÜSCHEL, F. P.; MACHADO, M. R. A. O raciocínio jurídico-dogmático e suas relações com o funcionamento do Poder Judiciário e a democracia. In: José Rodrigo Rodriguez; Flávia Portella Püschel, Marta Rodriguez Assis Machado. (Org.). Dogmática é conflito: uma visão crítica da racionalidade jurídica. 1ed. São Paulo: Saraiva, 2012, p. 35.

${ }_{13}$ RODRIGUEZ, J. R.; PÜSCHEL, F. P.; MACHADO, M. R. A. O raciocínio jurídico-dogmático e suas relações com o funcionamento do Poder Judiciário e a democracia. In: José Rodrigo Rodriguez; Flávia Portella Püschel, Marta Rodriguez Assis Machado. (Org.). Dogmática é conflito: uma visão crítica da racionalidade jurídica. 1ed. São Paulo: Saraiva, 2012, p. 36-43.

${ }_{14}$ RODRIGUEZ, J. R.; PÜSCHEL, F. P.; MACHADO, M. R. A. O raciocínio jurídico-dogmático e suas relações com o funcionamento do Poder Judiciário e a democracia. In: José Rodrigo Rodriguez; Flávia Portella Püschel, Marta Rodriguez Assis Machado. (Org.). Dogmática é conflito: uma visão crítica da racionalidade jurídica. 1ed. São Paulo: Saraiva, 2012, p. 59. 
Para fins de registro, críticas a essa doutrina não querem dizer que se ignora a caótica e calamitosa situação da população carcerária ou que o STF deva cruzar os braços para graves violações de direitos fundamentais. Entretanto, não é possível furtar a descrever, explicar e expor os problemas de empréstimos no campo teórico, inclusive para evitar que a situação se agrave, agora que todos os poderes públicos estão na berlinda para encontrar uma solução rápida e eficaz para o problema, sob pena de a eventual falha do $\mathrm{ECI}$ macular a legitimidade do STF e expor os riscos de experimentos decisórios com direitos fundamentais e com as relações institucionais entre os poderes.

\section{JULGAMENTO DA MC NA ADPF 347: EXPOSIÇÃO DESCRITIVA DOS VOTOS DOS MINISTROS}

O Partido Socialismo e Liberdade (PSOL) buscou, por meio de ADPF protocolada no dia 27 de maio de 2015, o reconhecimento da figura do $\mathrm{ECl}$ relativamente ao sistema penitenciário brasileiro e a adoção de providências estruturais em face de lesões a preceitos fundamentais dos atualmente encarcerados, que o partido alega decorrerem de ações e omissões dos poderes públicos da União, dos estados e do Distrito Federal. A relatoria do caso coube ao Ministro Marco Aurélio, que entendeu pelo reconhecimento de uma nova modalidade de inconstitucionalidade por omissão estrutural no direito brasileiro, o Estado de Coisas Inconstitucional (ECl) ${ }^{15}$.

Após descrever a deplorável situação da população carcerária no Brasil, o relator confirmou que dela decorrem inúmeras violações de direitos fundamentais e humanos ${ }^{16}$, bem como de preceitos básicos presentes na Lei de Execução Penal (Lei n 7.210, de 1984). Tais violações, de acordo com o ministro, não impactariam, tão somente, situações subjetivas

\footnotetext{
${ }^{15}$ BRASIL. Supremo Tribunal Federal. Medida Cautelar na ADPF 347. ADPF no 347. PARTIDO SOCIALISMO E LIBERDADE. Relator: Ministro Marco Aurélio. 09 de Setembro de 2015. Disponível em: http://redir.stf.jus.br/paginadorpub/paginador.jsp?docTP=TP\&docID=10300665. Acesso em: 18 set 2017.

16 O princípio da dignidade da pessoa humana (artigo $1^{\circ}$, inciso III); a proibição de tortura e tratamento desumano ou degradante de seres humanos (artigo $5^{\circ}$, inciso III); a vedação da aplicação de penas cruéis (artigo $5^{\circ}$, inciso XLVII, alínea "e"); o dever estatal de viabilizar o cumprimento da pena em estabelecimentos distintos, de acordo com a natureza do delito, a idade e sexo do apenado (artigo $5^{\circ}$, inciso XLVIII); a segurança dos presos à integridade física e moral (artigo $5^{\circ}$, inciso XLIX); e os direitos à saúde, educação, alimentação, trabalho, previdência e assistência social (artigo $6^{\circ}$ ) e à assistência judiciária. BRASIL. Supremo Tribunal Federal. Medida Cautelar na ADPF 347. ADPF $n^{\circ}$ 347. PARTIDO SOCIALISMO E LIBERDADE. Relator: Ministro Marco Aurélio. 09 de Setembro de 2015. Disponível em: http://redir.stf.jus.br/paginadorpub/paginador.jsp?docTP=TP\&docID=10300665. Acesso em: 18 set 2017, p. 25.
} 
individuais, mas afetariam toda a sociedade. Portanto, concluiu que, no Brasil, cárceres não serviam à ressocialização.

A responsabilidade por essa situação recai sob os três poderes, em todos os níveis da Federação, muito embora o problema do $\mathrm{ECl}$ não seja de formulação e implementação de políticas públicas, ou de interpretação e aplicação da lei penal, mas da falta de coordenação institucional para sua concretização. Trata-se, argumenta o relator, de uma situação de inércia ou omissão que ocasiona problemas estruturais na concretização normativa da Constituição e da legislação correlata, e nada é feito para melhorar a situação. A ausência de medidas legislativas, administrativas e orçamentárias eficazes representam falha estrutural apta a gerar tanto a violação sistemática dos direitos fundamentais dos encarcerados quanto a perpetuação e o agravamento da situação ${ }^{17}$.

Em face desses entraves, o STF deve desempenhar um papel importante e uma das formas de atuação do tribunal seria dar vazão ao litígio estrutural por meio do $\mathrm{ECl}$, cuja utilização e cabimento depende da demonstração de três pressupostos: 1) situação de violação generalizada de direitos fundamentais; 2) inércia ou incapacidade reiterada e persistente das autoridades públicas em modificar a situação identificada e 3) que a superação das transgressões exija a atuação de todas as autoridades políticas ${ }^{18}$.

Nesse momento do voto, Marco Aurélio sustenta que é impossível indicar, com segurança, os problemas brasileiros que se encaixariam nesse conceito e, em seguida, cita nominalmente os exemplos do saneamento básico, da saúde pública e da violência urbana. Mas confirma que o caso do sistema carcerário seria uma hipótese de certeza positiva. Dessa forma, caberia ao STF, de forma excepcional, atuar de forma mais assertiva, por ser o órgão capaz de superar os bloqueios políticos e institucionais que vêm impedindo o avanço de soluções concretas - caberia

${ }^{17}$ BRASIL. Supremo Tribunal Federal. Medida Cautelar na ADPF 347. ADPF no 347. PARTIDO SOCIALISMO E LIBERDADE. Relator: Ministro Marco Aurélio. 09 de Setembro de 2015. Disponível em: http://redir.stf.jus.br/paginadorpub/paginador.jsp?docTP=TP\&docID=10300665. Acesso em: 18 set 2017, p. 27.

18 Trecho da Ementa da ADPF 347: “Presente quadro de violação massiva e persistente de direitos fundamentais, decorrente de falhas estruturais e falência de políticas públicas e cuja modificação depende de medidas abrangentes de natureza normativa, administrativa e orçamentária, deve o sistema penitenciário nacional ser caraterizado como "estado de coisas inconstitucional". BRASIL. Supremo Tribunal Federal. Medida Cautelar na ADPF 347. ADPF $n^{\circ}$ 347. PARTIDO SOCIALISMO E LIBERDADE. Relator: Ministro Marco Aurélio. 09 de Setembro de 2015. Disponível em: http://redir.stf.jus.br/paginadorpub/paginador.jsp?docTP=TP\&doclD=10300665. Acesso em: 18 set 2017, p. 03. 
à corte, então, a ação de retirar os demais poderes da inércia, catalisar debates, discutir novas políticas públicas, coordenar ações e monitorar os resultados ${ }^{19}$.

No caso da população carcerária, seriam dois os bloqueios institucionais presentes: a) sub-representação parlamentar (presos não podem votar ou serem votados) e impopularidade dos indivíduos (não há prioridade política dos gastos públicos com essas pessoas, ou seja, constituem uma minoria socialmente desprezada). Tendo em vista que a opinião pública está no coração da estrutura democrático-parlamentar, sustenta Marco Aurélio ${ }^{20}$, ignorá-la poderia significar não só o fracasso das políticas defendidas pelos parlamentares, mas também das tentativas de reeleição a cargos no Legislativo e no Executivo. Nesse sentido, diferentemente do que ocorre com a saúde pública, nas palavras do ministro:

comparem com a saúde pública: há defeitos estruturais sérios nesse campo, mas tem-se vontade política em resolvê-los. Não existe um candidato que não paute a campanha eleitoral, entre outros temas, na melhoria do sistema. Todos querem ser autores de propostas que elevem a qualidade dos serviços. Deputados lutam pela liberação de recursos financeiros em favor da população das respectivas bases e territórios eleitorais. A saúde pública sofre com déficits de eficiência, impugnados judicialmente por meio de um sem-número de ações individuais, mas não corre o risco de piora significativa em razão da ignorância política ou do desprezo social. O tema possui apelo democrático, ao contrário do sistema prisional $^{21}$.

Nesse cenário, de acordo com o ministro ${ }^{22}$, de bloqueios políticos insuperáveis, de fracasso de representação política dos presos, de pontos cegos legislativos e de temores de custos políticos aos congressistas, a intervenção do Supremo, na medida correta e suficiente, não poderia sofrer qualquer objeção de natureza democrática. Não é a autorização de substituição de tarefas próprias dos demais poderes, pois o STF deve superar bloqueios políticos

${ }^{19}$ BRASIL. Supremo Tribunal Federal. Medida Cautelar na ADPF 347. ADPF $n^{\circ}$ 347. PARTIDO SOCIALISMO E LIBERDADE. Relator: Ministro Marco Aurélio. 09 de Setembro de 2015. Disponível em: http://redir.stf.jus.br/paginadorpub/paginador.jsp?docTP=TP\&docID=10300665. Acesso em: 18 set 2017, 30-31.

${ }^{20}$ BRASIL. Supremo Tribunal Federal. Medida Cautelar na ADPF 347. ADPF $n^{\circ}$ 347. PARTIDO SOCIALISMO E LIBERDADE. Relator: Ministro Marco Aurélio. 09 de Setembro de 2015. Disponível em: http://redir.stf.jus.br/paginadorpub/paginador.jsp?docTP=TP\&docID=10300665. Acesso em: 18 set 2017, p. 33.

${ }^{21}$ BRASIL. Supremo Tribunal Federal. Medida Cautelar na ADPF 347. ADPF $n^{\circ}$ 347. PARTIDO SOCIALISMO E LIBERDADE. Relator: Ministro Marco Aurélio. 09 de Setembro de 2015. Disponível em: http://redir.stf.jus.br/paginadorpub/paginador.jsp?docTP=TP\&docID=10300665. Acesso em: 18 set 2017, p. 33.

22 BRASIL. Supremo Tribunal Federal. Medida Cautelar na ADPF 347. ADPF n 347. PARTIDO SOCIALISMO E LIBERDADE. Relator: Ministro Marco Aurélio. 09 de Setembro de 2015. Disponível em: http://redir.stf.jus.br/paginadorpub/paginador.jsp?docTP=TP\&docID=10300665. Acesso em: 18 set 2017, p. 33. 
e institucionais sem afastar esses Poderes dos processos de formulação e implementação das soluções necessárias. Deverá agir, porém, em diálogo com os outros Poderes e com a sociedade. Caberia ao Supremo, então, catalisar ações e políticas públicas, coordenar a atuação dos órgãos do Estado na adoção dessas medidas e monitorar a eficiência das soluções.

Cumpriria ao STF, no caso de um ECI, formular ordens flexíveis, com margem de criação legislativa e de execução a serem esquematizadas e concretizadas pelos demais Poderes, cabendo-lhe reter a jurisdição para monitorar a observância da decisão e o sucesso dos meios escolhidos. O tribunal funcionaria como um coordenador institucional que produz um efeito desbloqueador, e não um elaborador de políticas públicas. Fachin, Barroso, Zavascki, Weber, Fux, Cármen Lúcia, Celso de Mello e Lewandowski repetiram ${ }^{23}$, com pouca variação, os argumentos defendidos por Marco Aurélio, o que isenta de reproduzi-los no momento.

\section{CRÍTICAS À CARACTERIZAÇÃO DOGMÁTICA DO ECI NO BRASIL: A INCRÍVEL DOUTRINA DE UM CASO SÓ}

$\mathrm{O} \mathrm{ECl}$ é uma criação da ativista Corte Constitucional Colombiana. $\mathrm{O}$ adjetivo não indica uma avaliação negativa da atuação daquela corte, mas um adjetivo aposto pela literatura especializada ${ }^{24}$. Contudo, esse dado é importante para explicar a criação do $\mathrm{ECl}$ em um país com tantos problemas estruturais de violações de direitos humanos como a Colômbia.

Uprimny $^{25}$ lista algumas características específicas do Estado colombiano que ajudam a explicar a crescente judicialização da política no país: a) pouco apego à ideia de representação democrática, tendo em vista o passado de usurpação de poderes e a crônica corrupção política; b) tradição histórica de movimentos sociais fracos, quando comparados a outros países latinoamericanos (Argentina, por exemplo); c) fácil acesso à justiça constitucional; e d) a perda de espaço na política daqueles que defenderam direitos fundamentais de cunho social mais forte na constituinte, enfraquecendo a concretização das promessas sociais da Constituição.

\footnotetext{
${ }^{23}$ BRASIL. Supremo Tribunal Federal. Medida Cautelar na ADPF 347. ADPF n 347. PARTIDO SOCIALISMO E LIBERDADE. Relator: Ministro Marco Aurélio. 09 de Setembro de 2015. Disponível em: http://redir.stf.jus.br/paginadorpub/paginador.jsp?docTP=TP\&docID=10300665. Acesso em: 18 de Setembro de 2017.

${ }^{24}$ CEPEDA-ESPINOSA, Manuel José. Judicial Activism in a Violent Context: The Origin, Role, and Impact of the Colombian Constitutional Court. In: Washington University Global Studies Law Review, Vol. 3, 2004, pp. 529/691. BETANCUR HINCAPIE, Guillermo Leon. Activismo de la Corte Constitucional ColombianaArgumentos que lo justifican. In: Nuevo Derecho, v.10, 2014, p. 09 - 20.

25 UPRIMNY, Rodrigo. Judicialization of Politics in Colombia: Cases, Merits and Risks. In: Sur - International Journal on Human Rights, Vol. 6, 2007, p. 57-59.
} 
Dentro desse contexto, o $\mathrm{ECl}$ se destaca como uma das mais importantes e exportáveis criações da Corte Constitucional Colombiana (CCC), apesar de sua aplicação local errática e esparsa. Oficialmente, o instituto foi utilizado pela CCC em, pelo menos, sete oportunidades: 1) docentes municipais contribuintes de fundo previdenciário municipal que negou-lhes cobertura de saúde (SU-559/97); 2) demora administrativa na resposta às petições de aposentados acerca de recálculos e diferenças previdenciárias (T - 068/98); 3) superlotação carcerária e condições desumanas nas penitenciarias de Bogotá e Medellín ( $T$ - 153/98); 4) ausência de concursos públicos para o cargo de notários (SU - 250/98); 5) ausência de políticas públicas para a proteção de defensores de direitos humanos (T - 590/98); 6) demora municipal no pagamento das verbas de aposentadoria e pensão ( $T$ - 525/99) e 7) deslocamento forçado de pessoas em função dos conflitos armados internos $(T-025 / 04)^{26}$.

A construção do conceito de ECI na jurisprudência da corte colombiana foi incremental, percurso que não poderá ser descrito neste trabalho por questões de espaço, mas sua feição mais recente, especialmente quanto aos seus requisitos, pode ser exposta da seguinte forma ${ }^{27}$ : 1) vulneração massiva e generalizada de vários direitos constitucionais, capaz de afetar um número significativo de pessoas; 2) prolongada omissão das autoridades no cumprimento de suas obrigações pra garanti-los; 3) a adoção de práticas inconstitucionais, tal como a incorporação da ação de tutela como parte do procedimento para garantir o direito; 4) a não expedição de medidas legislativas, administrativas ou orçamentárias necessárias para evitar a vulneração de direitos; 5) a existência de um problema social cuja solução compromete a intervenção de várias entidades, adoção de um conjunto complexo e coordenado de ações que exigem um nível de recursos que demanda um esforço orçamentário adicional; e 6) se todas as pessoas afetadas pelo mesmo problema acudirem à ação de Tutela para obter a proteção de seus direitos, produziria congestionamento judicial ${ }^{28}$.

Feitas essas breves exposições descritivas do caso colombiano, tendo em vista que não é do interesse do presente artigo explicar o $\mathrm{ECl}$ na Colômbia, é possível passar a analisar o exemplo brasileiro correlacionando com as críticas feitas ao instituto na origem.

${ }^{26}$ CAMPOS, Carlos Alexandre de Azevedo. Estado de Coisas Inconstitucional. Salvador: Juspodivm, 2016. p. $121-153$.

27 No Brasil: CAMPOS, Carlos Alexandre de Azevedo. Estado de Coisas Inconstitucional. Salvador: Juspodivm, 2016.

28 SUELT COCK, Vanessa. El estado de cosas de inconstitucionalidade. In: 20 Años de la Constitución Colombiana: logros, retrocesos y agenda pendiente. INÉS ACOSTA, Juana -López. et al (eds.). Bogotá: Fundación Konrad Adenauer, 2012. p. 207. 


\section{REVISÃO DOGMÁTICA DOS PRESSUPOSTOS DE CABIMENTO DO ECI}

\section{BRASILEIRO}

O STF elencou, supostamente, apenas três pressupostos para a caracterização e consequente cabimento do $\mathrm{ECl}$ : a violação generalizada de direitos humanos, a omissão estrutural dos três poderes e a solução complexa que demanda ação conjunta dos poderes. Ausentes, portanto, as hipóteses orçamentárias e de acesso à justiça consideradas pela CCC. Em seguida, analisa-se aqueles pressupostos de forma conjunta e sobreposta.

Sobre a violação generalizada de direitos fundamentais, o STF não se aprofundou na caracterização do que seriam elas, para fins de cabimento do $\mathrm{ECl}$, provavelmente porque a barbárie da situação carcerária brasileira seja tão evidente que dispense maiores demonstrações empíricas e construções teóricas.

Para utilizar uma noção análoga desenvolvida por Medina Quiroga ${ }^{29}$ no campo do Direito Internacional dos Direitos Humanos, violações sistemáticas de Direitos Humanos são aquelas caracterizadas por servir de instrumental para a realização e o sucesso de determinada política governamental, perpetradas em tal quantidade e de tal maneira a criar uma situação em que os direitos à vida, à integridade pessoal e à liberdade pessoal da população de um Estado, como um todo ou de um ou mais setores, sejam continuamente violados ou ameaçados. Um rol semelhante de direitos é destacado pela Corte Interamericana de Direitos Humanos (Corte IDH) ${ }^{30}$ para caracterizar violações sistemáticas de Direitos Humanos.

$\mathrm{Na}$ ADPF 347, por outro lado, não é possível afirmar que o tribunal brasileiro tenha adotado os conceitos de "violações sistemáticas" ou "violações massivas" oriundos do Direito Internacional dos Direitos Humanos em razão da ausência do elemento "política governamental", ou seja, quando o próprio Estado emprega uma política, de forma dolosa, com a finalidade de violar Direitos Humanos e a não delimitação em uma classe específica de modalidades violadoras de Direitos Humanos. Portanto, a noção de "violações generalizadas" de Direitos Fundamentais parece ser uma categoria de Direito Constitucional brasileiro, demandando maiores explicações e contornos seguros no sentido de sua identificação em casos posteriores.

\footnotetext{
${ }^{29}$ MEDINA QUIROGA, Cecilia. Los 40 años de la Convención Americana sobre Derechos Humanos a la luz de cierta jurisprudencia de la Corte Interamericana. In: Anuario de derechos humanos, $n^{\circ}$ 05, Santiago, p. 15-34, 2009, p. 21.

30 Tortura, execuções sumárias, extralegais ou arbitrárias e desaparecimentos forçados. Cfr. Caso Barrios Altos Vs. Perú. Fondo. Sentencia de 14 de marzo de 2001. Serie C No. 75, § 41; Caso Gomes Lund y otros (Guerrilha do Araguaia), 2010, § 257, y Caso Gelman v Uruguay, 2011, § 225.
} 
Marco Aurélio e os demais ministros apenas descreveram a situação do sistema carcerário brasileiro, e elencaram os direitos fundamentais que teriam sido violados, acrescentando que, naquelas hipóteses, há a transgressão da dignidade da pessoa humana e do mínimo existencial ${ }^{31}$. Portanto, para o STF, uma violação generalizada de direitos fundamentais envolve aspectos quantitativos, mais de um direito fundamental violado, atingindo uma grande quantidade de pessoas (sem maiores discussões acerca da viabilidade desse grupo ser determinável ou não) e aspectos qualitativos, transgressões à dignidade humana que atingem o mínimo existencial ${ }^{32}$.

Com efeito, partindo do aspecto quantitativo que caracteriza uma violação generalizada (violação de mais de um direito fundamental de um grupo de pessoas), o STF não qualificou a natureza dos direitos fundamentais envolvidos (direitos individuais, sociais, coletivos etc.), se a violação será estimada a partir de direitos considerados individualmente (violação do direito à vida de cada um dos encarcerados) ou do grupo como um todo (direito de associação, direito ao meio ambiente, direito à saúde, integridade física e psicológica, educação etc.).

Por exemplo, no caso da ADPF 347, fora violada a garantia de não ser torturado de cada um dos encarcerados contabilizados como pessoa ou do grupo em si a depender do estabelecimento prisional? Tal especificação é importante, pois podemos nos deparar com violações generalizadas de quaisquer direitos fundamentais em qualquer contexto, sejam eles individuais ou sociais, se optarmos pela categorização individualizada pessoa a pessoa. Nessa toada, jornalistas podem alegar uma violação generalizada de direitos fundamentais se estiverem aptos a demonstrar que houve uma violação, em circunstâncias particulares, de seu direito à liberdade de expressão e de imprensa por conta de decisões judiciais prolatadas por diferentes tribunais do país ao longo dos 30 anos de vigência da Constituição, argumentando a inércia legislativa em criar espaço para o exercício da liberdade de imprensa.

A exigência de que a violação alcance mais de um direito fundamental pode ser facilmente contemplada, porquanto em uma demanda que envolva direitos fundamentais, dificilmente apenas um direito estará sendo posto em evidência. Quando uma pessoa requer ao

\footnotetext{
${ }^{31}$ Nas palavras de Marco Aurélio na ADPF 347: "A forte violação de direitos fundamentais, alcançando a transgressão à dignidade da pessoa humana e ao próprio mínimo existencial justifica a atuação mais assertiva do Tribunal". BRASIL. Supremo Tribunal Federal. Medida Cautelar na ADPF 347. ADPF n 347. PARTIDO SOCIALISMO E LIBERDADE. Relator: Ministro Marco Aurélio. 09 de Setembro de 2015. Disponível em: http://redir.stf.jus.br/paginadorpub/paginador.jsp?docTP=TP\&docID=10300665. Acesso em: 18 set 2017. p. 31.

32 Campos parece concordar, no ponto, ao estipular três critérios: i) violação massiva de direitos fundamentais (o autor não conceitua 'violação massiva'); ii) variedade de direitos fundamentais envolvidos (individuais, sociais etc.) e iii) não alcancem populações locais ou restritas, mas um número elevado e amplo, especialmente grupos vulneráveis. CAMPOS, Carlos Alexandre de Azevedo. In: Estado de Coisas Inconstitucional. Salvador: Juspodivm, 2016. p. 180.
} 
Poder Judiciário que o Estado forneça um medicamento previsto nos protocolos do SUS, mas que não lhe fora dispensado por problemas administrativos, podemos argumentar que estão em jogo os direitos à vida (art. 5 , caput, Constituição da República Federativa do Brasil - CRFB), integridade física, saúde (art. $6^{\circ}$, caput, CRFB), igualdade (art. $5^{\circ}$, caput, CRFB) etc. No caso dos jornalistas citado no parágrafo anterior, podemos citar o direito à liberdade de consciência (art. $\left.5^{\circ}, \mathrm{VI}, \mathrm{CRFB}\right)$, vedação de censura (art. 220, $\S 2^{\circ}, \mathrm{CRFB}$ ) e à plena liberdade de informação jornalística (art. 220, § $\left.1^{\circ}, \mathrm{CRFB}\right)^{33}$.

Por sua vez, o aspecto qualitativo, ou seja, a violação transgressora da dignidade que atinja o mínimo existencial pode ser demonstrada facilmente, uma vez que a dignidade da pessoa humana, conforme o próprio tribunal, está presente como critério fundamental e justificador de todos os direitos fundamentais da Constituição brasileira. Amancia ${ }^{34}$ identificou que o STF considera a dignidade da pessoa humana como base para a aplicação dos direitos individuais $(81,3 \%)$, sociais $(16,9 \%)$ e coletivos $(1,8 \%)$, muito embora a primeira categoria de direitos tenha maior proeminência na quantidade de julgados analisados (59). Dessa forma, qualquer violação a Direitos Fundamentais resvala na dignidade humana, a menos que os ministros estejam sugerindo a existência de violações de direitos fundamentais que não atinjam a dignidade humana.

Por fim, parece haver uma ligação umbilical e indissociável entre dignidade, mínimo existencial e direitos fundamentais. Se o Estado está obrigado, especialmente na seara dos direitos sociais, a prestar apenas aquilo que se considera como o mínimo para uma existência digna, então o que estiver fora dessa esfera será, embora desejável, não justificável como obrigação estatal derivada de um dever fundamental público.

Dito em outras palavras: existiria, então, uma obrigação estatal caracterizada como um direito fundamental que está fora da ideia de mínimo existencial? Somos titulares do direito social à moradia, mas nele está incluído uma cobertura no Leblon para cada um de nós? Se a resposta for negativa, é porque existe um âmbito específico de conteúdo desse direito que limita a obrigação do Estado a sua fundamentalidade e, muito provavelmente, este âmbito será o mínimo existencial a ser exigido do Estado. Do contrário, estaria sendo sugerido que o Estado está obrigado a concretizar um conteúdo do direito social à moradia que não é essencial ou

33 BRASIL. Constituição Federal. Brasília: Senado Federal, 1988. Disponível em: http://www.planalto.gov.br/ccivil_03/Constituicao/Constituiçao.htm. Acesso em: 9 jun 2018.

${ }^{34}$ AMANCIA, Natália Alves. O princípio da dignidade da pessoa humana na jurisprudência do STF. 2010. Monografia (Aperfeiçoamento/Especialização em Escola de Formação) - Sociedade Brasileira de Direito Público, p. 21. 
relevante para a dignidade humana, ou seja, algo não fundamental. Com efeito, se um direito fundamental for violado, o mínimo existencial da pessoa humana também o será.

Da mesma forma que o argumento anterior sobre a ideia de que uma violação a direitos fundamentais sempre afetará, necessariamente, a dignidade humana, seria possível pensar em um caso no qual o STF reconheça a existência de uma violação a um direito fundamental social, mas que não tenha atingido, negativamente, o mínimo existencial da pessoa? Se há o direito a um tratamento a diabetes e o Estado, alegando razões financeiras, deixa de fornecê-lo regularmente, como separar, nesse caso, o mínimo existencial da parcela de direito fundamental da qual é titular o cidadão, mas que está situada fora desse mínimo?

Longe de ser um detalhe trivial, a ausência de um delineamento mais acurado acerca da identificação do que seria uma violação generalizada de direitos fundamentais atraiu contundentes críticas à jurisprudência da CCC sobre o $\mathrm{ECl}^{35}$. Em um primeiro ciclo de decisões (97-98), a Corte Colombiana considerou a falta de concurso público para o cargo de notários e a demora na resposta administrativa de peticionamento acerca de recálculos previdenciários uma grave violação de direitos fundamentais, por exemplo.

As suspeitas da academia colombiana acerca da aleatoriedade na utilização do $\mathrm{ECl}$ e, em última análise, de sua necessidade foram confirmadas quando a corte julgou os casos sobre direito à saúde $(T-460 / 08)^{36}$. Muito embora tenha constatado vulneração massiva de direitos fundamentais à saúde e representar um dos principais problemas colombianos ${ }^{37}$, a corte não fez uso de sua doutrina importada pelo STF, não obstante ter determinado a utilização das medidas reparatórias geralmente exigidas nos casos posteriores, especialmente, na T - 025/04.

35 SUELT COCK, Vanessa. El estado de cosas de inconstitucionalidade. 20 Años de la Constitución Colombiana: logros, retrocesos y agenda pendiente. INÉS ACOSTA, Juana -López. et al (eds.). Bogotá: Fundación Konrad Adenauer, 2012, p. 206 e RODRÍGUEZ-GARAVITO, César. ¿Cuándo cesa el estado de cosas inconstitucional del desplazamiento? Más allá del desplazamiento, o cómo superar un estado de cosas inconstitucional.In.: Más allá del desplazamiento: políticas, derechos y superación del desplazamiento forzado en Colombia. coordinador César Rodríguez Garavito; Juan Carlos Guataquí. et al. Bogotá: Universidad de los Andes, Facultad de Derecho, Ediciones Uniandes, 2009, p. 447 e inclusive de seus entusiastas, cf. no Brasil, CAMPOS, Carlos Alexandre de Azevedo. Estado de Coisas Inconstitucional. Salvador: Juspodivm, 2016. p. 167.

36 SUELT COCK, Vanessa. El estado de cosas de inconstitucionalidade. 20 Años de la Constitución Colombiana: logros, retrocesos y agenda pendiente. INÉS ACOSTA, Juana -López. et al (eds.). Bogotá: Fundación Konrad Adenauer, 2012. p. 206.

37 SUELT COCK, Vanessa. El estado de cosas de inconstitucionalidade. 20 Años de la Constitución Colombiana: logros, retrocesos y agenda pendiente. INÉS ACOSTA, Juana -López. et al (eds.). Bogotá: Fundación Konrad Adenauer, 2012. p. 215-221. 
Como sugere Rodriguez Garavito ${ }^{38}$, mesmo tendo consolidado a doutrina na T - 025/04, a CCC manteve as incertezas quanto à caracterização dos casos estruturais e sua consequente inaplicação nos litígios constitucionais que parecem cumprir com todos os requisitos, tal como ocorrera na situação da saúde ${ }^{39}$. Seguindo o mesmo trajeto, o STF parece demonstrar que da violação de qualquer direito fundamental, desde que cumpridos os requisitos quantitativos e qualitativos, caberá o $\mathrm{ECl}^{40}$.

Campos $^{41}$ tenta afastar tal crítica relembrando que o $\mathrm{ECl}$ será cabível apenas "em casos extraordinários de violação de direitos decorrentes de falhas estruturais", ou seja, para o autor devemos distinguir as "situações verdadeiramente inconstitucionais daquelas ruins, embora constitucionais".

A discricionariedade e fluidez na decretação do $\mathrm{ECl}$ permaneceriam ainda se adotássemos o critério de Campos acima referido, pois o autor parece sugerir que no Direito Constitucional brasileiro podemos separar e identificar as seguintes hipóteses: a) casos ordinários de violações de direitos fundamentais não decorrentes de falhas estruturais, os quais não ensejam a decretação do $\mathrm{ECl}$ (situação ruim, mas constitucional); b) casos ordinários de violações de direitos fundamentais decorrentes de falhas estruturais, que não ensejam a decretação do $\mathrm{ECl}$ (situação muito ruim, mas não inconstitucional) e c) casos extraordinários de violação de direitos fundamentais decorrentes de falhas estruturais, que ensejam a decretação do $\mathrm{ECl}$ (situação péssima e inconstitucional).

${ }^{38}$ RODRÍGUEZ-GARAVITO, César. ¿Cuándo cesa el estado de cosas inconstitucional del desplazamiento? Más allá del desplazamiento, o cómo superar un estado de cosas inconstitucional.In.: Más allá del desplazamiento: políticas, derechos y superación del desplazamiento forzado en Colombia. coordinador César Rodríguez Garavito; Juan Carlos Guataquí. et al. Bogotá: Universidad de los Andes, Facultad de Derecho, Ediciones Uniandes, 2009. p. 437.

${ }^{39}$ Bustamante argumenta que a CCC não decretou o $\mathrm{ECl}$ da saúde porque existiriam recursos financeiros suficientes, além de poder ser constatada uma infraestrutura prévia para a proteção dos direitos de seus usuários. Portanto, não se trataria de uma falha total do Estado, mas de um problema ocasionado por desvios do sistema. BUSTAMANTE, Gabriel. Estado de cosas inconstitucional y políticas públicas. Dissertação (Mestrado em Estudos Políticos) - Pontificia Universidad Javeriana, Colômbia, Bogotá, 2011. p. 11-18. O argumento do autor não convence, pois o caos do sistema carcerário não é, apenas, um caso de falha total do Estado, na medida em que medidas legislativas, administrativas e judiciais já haviam sido tomadas, muito embora inócuas ou ineficientes. Ademais, Colômbia concede aos tratados de direitos humanos posição privilegiada, tornando quaisquer situações fáticas desvios do sistema de garantias, que não correspondem ou atendem ao arcabouço de normas que protegem a população carcerária ou os usuários dos sistemas públicos de saúde.

${ }^{40}$ CAMPOS, Carlos Alexandre de Azevedo. Estado de Coisas Inconstitucional. Salvador: Juspodivm, 2016. p. 293-295.

41 CAMPOS, Carlos Alexandre de Azevedo. Estado de Coisas Inconstitucional. Salvador: Juspodivm, 2016. p. 293. 
De acordo com a formulação de Campos $^{42}$, não resta evidente porque situações ordinárias de violações de direitos fundamentais são consideradas apenas ruins, mas não inconstitucionais e porque apenas os casos extraordinários ensejam a aplicação do $\mathrm{ECl}$, se a lógica de proteção contra as omissões inconstitucionais que afetam os direitos fundamentais de forma estrutural pode surgir em outras hipóteses, como no caso da saúde, segurança pública e educação no Brasil. A distinção feita pelo autor parece legitimar a existência de violações generalizadas e estruturais de direitos fundamentais toleráveis pela Constituição e pelo Judiciário. Isso quer dizer que o STF deteria o monopólio para afirmar quando estaremos diante de uma situação excepcional para agir fora da Constituição.

Cabe discorrer, então, sobre a inércia ou incapacidade reiterada e persistente das autoridades públicas / solução complexa que demanda ação conjunta dos poderes. De início, é possível afirmar que não fica claro no voto de Marco Aurélio ${ }^{43}$ se o STF demanda uma omissão dos poderes (inércia), ou uma ineficiência executiva (há ação, mas ela é ineficiente), ou falta de vontade ou de incentivos políticos (há medidas, mas não são concretizadas porque os poderes não se sentem compelidos a tanto) ou se há a criação de medidas de qualidade duvidosa ou incapazes de resolver problemas estruturais (há a política, ela é aplicada de forma eficiente, mas é inócua para solucionar o problema do encarceramento). Vejamos o que afirma, textualmente, Marco Aurélio:

A inércia configura-se não apenas quando ausente a legislação, mas também se inexistente qualquer tentativa de modificação da situação, uma vez identificada a insuficiência da proteção conferida pela execução das normas vigentes.

[...]

A ausência de medidas legislativas, administrativas e orçamentárias eficazes representa falha estrutural a gerar tanto a violação sistemática dos direitos, quanto a perpetuação e o agravamento da situação"

[..]

Os poderes, órgãos e entidades federais e estaduais, em conjunto, vêm se mantendo incapazes e manifestando verdadeira falta de vontade em buscar superar ou reduzir o quadro objetivo de inconstitucionalidade. Faltam sensibilidade legislativa e motivação política do Executivo. ${ }^{44}$

42 CAMPOS, Carlos Alexandre de Azevedo. Estado de Coisas Inconstitucional. Salvador: Juspodivm, 2016. p. 293.

${ }^{43}$ BRASIL. Supremo Tribunal Federal. Medida Cautelar na ADPF 347. ADPF $n^{\circ}$ 347. PARTIDO SOCIALISMO E LIBERDADE. Relator: Ministro Marco Aurélio. 09 de Setembro de 2015. Disponível em: http://redir.stf.jus.br/paginadorpub/paginador.jsp?docTP=TP\&docID=10300665. Acesso em: 18 det 2017.

${ }^{44}$ BRASIL. Supremo Tribunal Federal. Medida Cautelar na ADPF 347. ADPF $n^{\circ}$ 347. PARTIDO SOCIALISMO E LIBERDADE. Relator: Ministro Marco Aurélio. 09 de Setembro de 2015. Disponível em: http://redir.stf.jus.br/paginadorpub/paginador.jsp?docTP=TP\&docID=10300665. Acesso em: 18 set 2017. p. 27. 
A ausência de claridade conceitual dificulta a construção dogmática do $\mathrm{ECl}$, pois não sabemos a métrica a ser utilizada para medir a atuação dos poderes públicos, e a corte não nos oferece as ferramentas necessárias para tanto. Nos parece, todavia, que o Relator faz a seguinte correlação: se há violações generalizadas de direitos fundamentais é porque há "falha estatal estrutural" e apenas o STF "revela-se capaz [...] de superar os bloqueios políticos e institucionais" ${ }^{45}$.

Portanto, o Ministro insere um elemento político de complexa identificação e configuração, mas que, ao mesmo tempo, nos dá indícios sobre a limitadíssima incidência do ECI: a suposta existência de bloqueios políticos. A função excepcional de um supremo aríete apenas seria suscitada nas hipóteses de falha estatal estrutural, independentemente de como essa falha se apresenta. Se é inercia, ou se é omissão, ou se as medidas são ineficazes, pouco importa, desde que elas sejam produto de um suposto bloqueio político. Isso poderia explicar o pouco cuidado na formulação do segundo critério explícito do $\mathrm{ECl}$ (Inércia ou incapacidade reiterada e persistente das autoridades públicas).

Contudo, como se está argumentando, na ausência de maiores esforções conceituais para definir o que seria uma falha estatal estrutural, se estivermos diante de uma violação generalizada de direitos não será difícil atribuí-la a uma falta de coordenação entre os poderes, contudo ela precisará ter sido ocasionada por um bloqueio político, muito embora esse critério não esteja presente na formulação tripartite simples de Marco Aurélio. Volta-se ao ponto em outro momento.

Apesar de ter ressaltado o argumento das capacidades institucionais limitadas da corte em outras oportunidades ${ }^{46}$, o STF considerou que o ECI lhe permitirá avaliar quando as

\footnotetext{
45 BRASIL. Supremo Tribunal Federal. Medida Cautelar na ADPF 347. ADPF no 347. PARTIDO SOCIALISMO E LIBERDADE. Relator: Ministro Marco Aurélio. 09 de Setembro de 2015. Disponível em: http://redir.stf.jus.br/paginadorpub/paginador.jsp?docTP=TP\&docID=10300665. Acesso em: 18 set 2017. p. 31.

${ }^{46}$ Rcl. 11.243 (O Judiciário não foi projetado pela Carta Constitucional para adotar decisões políticas na esfera internacional, competindo esse mister ao Presidente da República, eleito democraticamente e com legitimidade para defender os interesses do Estado no exterior), ADPF 387 (carece capacidade institucional [ao judiciário] para avaliar os impactos desses bloqueios e sequestros de verbas sobre atividade administrativa e programação financeira do ente federativo). 0 argumento das capacidades institucionais no STF, aparentemente, inspirou-se em artigo acadêmico de Sunstein e Vermeule, elaborado para dar conta dos problemas nas construções teóricas abrangentes e abstratas acerca da interpretação constitucional, tradicionalmente silentes sobre as nuances expostas pelas relações intra e interinstitucionais e sobre seus efeitos dinâmicos nas suas operacionalizações concretas. SUNSTEIN, Cass; VERMEULE, Adrian. Interpretation and Institutions. Michigan Law Review, vol. 101, pp. 885-951, 2003. Portanto, não se trata de um cabedal metodológico cuja função seja realizar um autodiagnostico sobre os limites constitucionais de atuação do Poder Judiciário quando assim the for conveniente. Do contrário, como argumentam Arguelhes e Leal, a utilização do fraseado "capacidade institucional" não acrescentaria
} 
autoridades públicas competentes demonstrarem inércia ou incapacidade para superar a situação de violação generalizada de direitos fundamentais, muito embora não tenha estabelecido padrões, critérios ou indicadores para aferi-las ${ }^{47}$.

Como poderá a corte aferir a inércia do Poder Legislativo? Uma inércia legislativa se opera nas hipóteses nas quais o legislador se abstiver de editar, alterar ou retirar uma lei específica sobre o tema? A edição de uma lei será suficiente para afastar a inércia? A apresentação de um Projeto de Lei sobre o tema será suficiente para afastar inércia? Como avaliar quando uma violação generalizada de direitos fundamentais estará fora da capacidade institucional do Poder Legislativo?

Quando o Judiciário será tido como inerte? Quando deixar de decidir ou decidir de forma equivocada? Uma decisão apenas bastaria para sanar a inércia, ou tão somente uma expressiva quantidade de decisões? O STF, órgão máximo do poder judiciário, e não uma Corte Constitucional, também poderá ser tido por inerte? Como justificar a competência exclusiva daquela corte para apresentar soluções ${ }^{48}$, uma vez que, para o cabimento do $\mathrm{ECl}$ a própria capacidade institucional do Judiciário será, necessariamente, questionada?

nada de novo para a análise do fenômeno investigado, travestindo-se de uma roupagem nova para o velho argumento da separação de poderes. ARGULHES, Diego Werneck; LEAL, Fernando. O argumento das 'capacidades institucionais' entre a banalidade, a redundância e o absurdo. Direito, Estado e Sociedade, v. 38,2014 , p. 35 . Os mesmos autores sugerem cautela, além de nutrirem desconfiança, sobre a possibilidade de o Judiciário operacionalizar todos os requisitos exigidos pela empreitada teórica para avaliar a capacidade institucional dos demais poderes LEAL, Fernando; ARGUELHES, Diego Werneck. Dois problemas de operacionalização do argumento das 'Capacidades Institucionais'. Revista de Estudos Institucionais, v. 2, p. 192-213, 2016.

47 Com a palavra, o relator Min. Marco Aurélio: "No tocante ao possível óbice atinente à separação de Poderes, à alegação das capacidades institucionais superiores do Legislativo e do Executivo comparadas às do Judiciário, há de se atentar para as falhas estruturais ante o vazio de políticas públicas eficientes". BRASIL. Supremo Tribunal Federal. Medida Cautelar na ADPF 347. ADPF n ${ }^{\circ}$ 347. PARTIDO SOCIALISMO E LIBERDADE. Relator: Ministro Marco Aurélio. 09 de Setembro de 2015. Disponível em: http://redir.stf.jus.br/paginadorpub/paginador.jsp?docTP=TP\&docID=10300665. Acesso em: 18 set 2017. p. 35.

$48 \mathrm{Em}$ seu voto na ADPF 347, Marco Aurélio prometeu diálogo com os demais poderes, a imposição de obrigações flexíveis e a retenção do cumprimento das decisões no STF, contudo, a tese do suposto diálogo entre os poderes não anda de mãos dadas com a explicação sobre capacidades institucionais. Infelizmente, por conta da natureza do artigo e do espaço limitado da nota, não poderemos expandir tanto o argumento, mas é importante destacar que o debate sobre diálogos institucionais nos EUA, cuja produção acadêmica serviu de fonte da tese que subsidiou o voto do ministro, tal como visto em Campos, não opera no campo normativo da atividade da Suprema Corte, ou seja, os autores que defendem a metáfora do diálogo, principalmente, Fisher, Pickerill e Whittington não sugerem que a Suprema Corte deva "ouvir" o legislativo, ou que eles trabalhem de forma cooperativa, alterando suas tradicionais formas de interação institucional (Revisão Judicial da lei -> resposta do Legislativo -> interpretação judicial da resposta legislativa), mas todos destacam, no plano descritivo e explicativo, a ideia de que a construção na interpretação da constitucional (não limitada aos Direitos Fundamentais) não é feita de forma isolada pela corte, mas depende das respostas legislativas, as quais revertem, confirmam ou alteram decisões judicias com leis que, por conseguinte, estarão sujeitas à revisão judicial posterior. Nenhum deles sugere 
O Executivo será omisso quando ele não criar uma política pública sobre a matéria pertinente à violação de direitos fundamentais ou quando a política se mostrar ineficiente? Caberá ao STF formular os padrões capazes de aferir a ineficiência de uma política pública criada pelo Executivo, quando o mesmo tribunal tem considerado que não detém as capacidades institucionais exigidas para tanto ou quando ele mesmo for a instituição tida como inerte?

O STF, como o faz rotineiramente, típico de uma corte que decide com base em argumentos de autoridade, não respondeu a nenhum desses questionamentos, favorecendo a discricionariedade e aleatoriedade na aplicação do $\mathrm{ECl}$ no futuro. Argumentos minimamente baseados na análise das capacidades institucionais dos poderes da República exigem certezas empíricas quanto ao grau de eficácia do exercício das competências das instituições no agregado, e não em situações pontuais ou em casos específicos ${ }^{49}$. Ou seja, a incapacidade ou inércia de um poder, separadamente considerado, ou em sua ação conjunta com os demais, não pode ser aferida por meio de intuições, senso comum ou fatos notórios.

Afirmar a inércia e incapacidade institucional do Congresso Nacional na ADPF 347 é um argumento bastante questionável, tendo em vista a profusão de leis e políticas públicas desenvolvidas nos últimos 30 anos sobre política carcerária. Por outro lado, outra linha argumentativa para manter a justificativa para um $\mathrm{ECl}$, contudo, seria sugerir a má qualidade dessa produção legislativa nacional, juízo avaliativo perigoso de ser colocado, exclusivamente, nas mãos do STF.

Ferreira e Machado argumentam que, a partir de uma CPI realizada em 1976, as péssimas condições prisionais e o controle de vagas atraíram a atenção dos poderes públicos, o que não resultou, necessariamente, em uma evolução qualitativa na produção legislativa sobre o sistema carcerário. As autoras argumentam que a grande maioria das propostas legislativas, leis e políticas públicas debatidas no Congresso no período analisado em sua pesquisa (1984-2011) ${ }^{50}$

a inserção de novos procedimentos interativos entre Corte e Parlamento, ou mesmo a extinção do controle de constitucionalidade. No voto na ADPF 347, o ministro caracteriza como diálogo o que ele entende que seja uma espécie de relação interinstitucional (decretação do $\mathrm{ECl}$, decretação de medidas flexíveis aos poderes e monitoramento), mas não explica os ganhos epistemológicos da metáfora para além da aplicação de sua construção norte-americana. Dessa forma, nos questionamos: como sustentar diálogo quando a corte é quem diz que o Executivo e Legislativo são incapazes de solucionar uma violação de direitos fundamentais (sem oportunidade de contraditório), quando a corte é quem impõe as medidas para superação do $\mathrm{ECl}$ (ainda que flexíveis) que devam ser cumpridas pelos poderes e quando é ela quem decide e avalia as medidas tomadas? Não basta afirmar que tal esquema é dialógico, é necessário explicar e demonstrar. CAMPOS, Carlos Alexandre de Azevedo. Estado de Coisas Inconstitucional. Salvador: Juspodivm, 2016. p. 242.

49 ARGULHES, Diego Werneck; LEAL, Fernando. 0 argumento das 'capacidades institucionais' entre a banalidade, a redundância e o absurdo. In: Direito, Estado e Sociedade, v. 38, 2014.

${ }^{50}$ As autoras analisaram 500 propostas legislativas neste período. 
gravitaram em torno do presídio como o lócus privilegiado para a punição criminal e na construção de teorias que buscassem justificar e pensar tal ambiente como capaz de cumprir com a reabilitação do indivíduo para a vida social. Ou seja, a sanção prisional e o presídio são o centro da política criminal no Brasil ${ }^{51}$.

Por meio da análise das proposições legislativas encaminhadas ao Congresso Nacional, as autoras identificaram o seguinte padrão: 1) a monotonia da intervenção jurídica como única solução para o problema do encarceramento e 2) o automatismo decisório aliado ao culto à quantificação em matéria de penas - em que se observa: a) prevalência da sanção prisional em detrimento de todas as demais qualidades de penas e b) a prática de estabelecer penas mínimas de prisão. Dos 1.688 tipos penais que compõem a legislação criminal brasileira, a pena de prisão está prevista em $97 \%$ deles.

Dentre os convênios firmados entre Estados e União (1994-2009), a quase exclusividade de investimentos ocorreu na ampliação e construção de estabelecimentos prisionais $(88,69 \%)$, restando $6,61 \%$ para aparelhamento; 3,32\% para reintegração e capacitação dos presidiários e apenas $1,36 \%$ destinado às penas alternativas.

Além de não terem afetado a taxa de encarceramento, nas justificativas dos projetos é possível constatar a percepção de que existem pessoas perigosas, não visibilizando o problema da violência a partir do ato, ou ação praticada, como exposto na LEP, mas em uma caracterização de indivíduos que estão fora e os que devem estar dentro das prisões ${ }^{52}$.

O Executivo, igualmente, não está cego ao problema, vide as ações do Ministério da Saúde (Plano Nacional de Saúde no Sistema Penitenciário de 2003 e Política Nacional de Atenção Integral à Saúde das Pessoas Privadas de Liberdade no Sistema Prisional de 2014), do Ministério da Educação, estabelecendo as Diretrizes Nacionais para Educação nas Prisões, e as leis frutos de projetos do Executivo, tal como o Programa Nacional de Segurança Pública com Cidadania (PRONASCI, lei 11.530/07), apenas para citar algumas políticas encetados pelo Governo Federal.

As dúvidas quanto à demonstração de omissão reiterada, falha estrutural e incapacidade institucional dos Poderes Públicos não são, outrossim, ilididas por meio da argumentação feita

\footnotetext{
${ }^{51}$ FERREIRA, Carolina Cutrupi; MACHADO, Maíra Rocha. Exclusão social como prestação do sistema de justiça: um retrato da produção legislativa atenta ao problema carcerário no Brasil. In: RODRIGUEZ, José Rodrigo. (Org.). Pensar o Brasil: Problemas nacionais à luz do direito. São Paulo: Saraiva, 2012. p. 78-82. 52 FERREIRA, Carolina Cutrupi; MACHADO, Maíra Rocha. Exclusão social como prestação do sistema de justiça: um retrato da produção legislativa atenta ao problema carcerário no Brasil. In: RODRIGUEZ, José Rodrigo. (Org.). Pensar o Brasil: Problemas nacionais à luz do direito. São Paulo: Saraiva, 2012. p. 93.
} 
pelos defensores do instituto do ECI. De acordo com Campos $^{53}$, a LEP (Legislativo) e o FUNPEN (Executivo) são importantes, mas fracassam de forma generalizada enquanto políticas públicas (o autor não demonstra, contudo, o critério utilizado para avaliar o fracasso ou sucesso das políticas públicas mencionadas). Em seguida, sustenta a "ausência de medidas legislativas, administrativas e orçamentarias eficazes", bem como a inexistência de "qualquer tentativa de alteração do quadro uma vez identificada a insuficiência da proteção conferida pela execução das normas vigentes".

Em primeiro lugar, a LEP não é o único produto do Congresso a tratar sobre o tema do encarceramento, e o autor não explicou como a rede legal de normas se insere no quadro de omissão reiterada ${ }^{54}$. A LEP é da década de 80 , mas outras leis foram produzidas desde então (alteração das penas no Código Penal, mudanças no Código de Processo Penal) ${ }^{55}$, a demonstrar que o Legislador não tratou a LEP como sua contribuição definitiva ou única sobre a matéria. Em segundo lugar, o Executivo não limitou sua atuação à criação do FUNPEN (94), tendo criado diversos programas (com a chancela do parlamento) para tentar remediar o caos instalado nos presídios, conforme o mencionado no parágrafo acima.

Portanto, o voto de Marco Aurélio e o texto de Campos $^{56}$ são omissos na estipulação de critérios que permitam ao leitor e ao próprio STF constatar: 1) os indicadores que apontem omissões estruturais, ou seja, falência de políticas públicas estatais mesmo na presença de diversas leis e atos normativos emaranhados (leis e atos normativos federais, nacionais e estaduais sobre segurança pública) e 2) como se caracteriza a ausência de tentativas de mudança ou superação do quadro de violações no aspecto temporal (diacrônico/sincrônico) e substantivo (de melhora na qualidade da intervenção política).

Por fim, ainda que se argumente que o objetivo do $\mathrm{ECl}$ é o de combater uma ineficácia estrutural completa, a decisão do STF não demonstrou a contento: 1) qual política pública é,

${ }^{53}$ CAMPOS, Carlos Alexandre de Azevedo. Estado de Coisas Inconstitucional. Salvador: Juspodivm, 2016. p. 272-273.

${ }^{54}$ Segue uma lista exemplificativa de leis, e regulamentação executiva, que tratam da temática criminal e impactam o sistema prisional brasileiro: a) Desarmamento: Lei 10.826/2003 (regulamentada pelo Decreto 9.685/2019); b) Crimes Hediondos: Lei 8.072/1990; c) Lavagem de dinheiro: Lei 9.613/1998; d) Maria da Penha: Lei 11.340/2006; e) Organizações criminosas: Lei 12.850/2013 (regulamentada pelo Decreto 9.527/2018); f) Terrorismo: Lei 13.260/2016 e g) Tortura: Lei 9.455/1997.

${ }^{55}$ Após a edição da LEP, o código penal foi alterado por meio de 62 leis federais (1984-2018) e o Código de Processo Penal foi alterado por 36 leis federais (1984-2018). Muitas dessas mudanças legislativas impactaram ou implicaram em reflexos no sistema penitenciário.

56 BRASIL. Supremo Tribunal Federal. Medida Cautelar na ADPF 347. ADPF no 347. PARTIDO SOCIALISMO E LIBERDADE. Relator: Ministro Marco Aurélio. 09 de Setembro de 2015. Disponível em: http://redir.stf.jus.br/paginadorpub/paginador.jsp?docTP=TP\&docID=10300665. Acesso em: 18 set 2017. CAMPOS, Carlos Alexandre de Azevedo. Estado de Coisas Inconstitucional. Salvador: Juspodivm, 2016. 
realmente, efetiva no Brasil; ou seja, uma política pública que está em curso e que, enfrentado problemas estruturais, não acarreta em grave violação de direitos fundamentais se ainda não cumpriu com seu objetivo? (fome zero erradicou a fome no Brasil? O programa 'minha casa, minha vida' solucionou o problema da moradia?) e 2) qual critério um intérprete deve utilizar para aferir uma ineficácia estrutural excepcional?

A complexidade do problema carcerário no Brasil, portanto, não se esgota em uma simples solução institucional, separada ou conjunta, mas se reflete na ideia de criminalidade, que, por sua vez, faz parte de uma questão mais ampla presente nas estruturas sócio-políticoeconômicas nacionais ${ }^{57}$.

Há uma percepção social no Brasil de que o encarceramento é a saída para o castigo da violação de uma transgressão criminal, tendo em vista a formação de um cidadão que não mereça estar na cadeia, visando, portanto, sua reabilitação. Debater o sistema carcerário exige uma reflexão social muito mais profunda sobre o papel do presídio, da pena de reclusão e do direito criminal, incapaz de ser posta a cabo por decisões judiciais, não importa o quão bemintencionadas ou escoradas em doutrinas estrangeiras de eficácia duvidosa. A solução para os problemas do sistema carcerário não estará nas mãos da Suprema Corte, mesmo que essa se pretenda aberta ao "diálogo" e à participação dos demais poderes na formulação de novas políticas públicas, que fracassarão igualmente se permanecerem ancoradas na lógica do encarceramento ${ }^{58}$.

Essa talvez seja a razão pela qual o $\mathrm{ECl}$ não tenha obtido êxito na solução do sistema carcerário Colombiano ${ }^{59}$. Ainda que a intervenção da CCC tenha sido saudada como necessária e

${ }^{57}$ CHIES, Luiz Antônio Bogo. A questão penitenciária. Tempo Social, São Paulo, v. 25, n. 1, p. 15-36, jun. 2013, p. 15.

${ }^{58}$ Landau sugere que o sucesso de injunções estruturais pode estar em alguns fatores sociais e políticos específicos. 0 relativo sucesso da CCC no caso dos deslocados internos pode ser creditado à inexistência de uma estrutura de políticas públicas prévias sobre o tema, diferindo das intervenções estruturais no caso da saúde, cuja burocracia já estava proposta, estruturada e com políticas públicas em moção. Sua reversão, portanto, traria enormes custos políticos. Podemos inserir, no caso brasileiro, um fator social (políticas públicas punitivistas e dirigidas ao encarceramento) como problemática para a eficácia da decisão do STF. Ou seja, o rumo das políticas existente vai determinar a forma de sua produção subsequente. LANDAU, David. The Reality of Social Rights Enforcement. Harvard International Law Journal, Vol. 53, Number 1, 2012, p. 227-229.

59 Recentemente, a própria CCC reconheceu o fracasso de sua intervenção: Casi 15 años después, la Sentencia T-388 de 2013, reconoció que los esfuerzos en la creación de una infraestructura penitenciaria que ampliara la cobertura fueron, en su mayoría, exitosos. Por tal motivo y al evidenciar que a pesar de los esfuerzos, la crisis permanecía vigente, en dicho fallo se hizo mayor énfasis en la necesidad de adecuar la política criminal del país, a los estándares y marcos de protección de los derechos de las personas privadas de la libertad, pues desde esa perspectiva se pueden lograr resultados mucho más sostenibles ( $T$ 762/15). No mesmo sentido, Campos (2016, p.133-134), para quem o equívoco da CCC foi determinar as alterações estruturais sem estabelecer procedimentos adequados de monitoramento. 
relevante $^{60}$ por ter atraído a atenção nacional para a causa, isso não significa que tenha solucionado a superlotação carcerária, a qual, pelo contrário, apenas aumentou após a decisão do $\mathrm{ECl}$, ou que tenha tido apoio ou simpatias acadêmicas unânimes ${ }^{61}$. Ariza ${ }^{62}$ realizou pesquisa de campo no estabelecimento prisional (La Modelo) que originou o caso T- 98, e pôde constatar que as condições de violência e condições indignas continuaram, com o presídio enquanto palco de enfrentamentos armados entre 2000 e 2001, resultando em inúmeros mortos ${ }^{63}$.

O autor, ademais, condena a associação feita entre as condições dos encarcerados e a as condições daqueles que não o estão, no sentido de uma natural equalização de ambas as situações em termos de garantia de direitos sociais. Garantir o desbloqueio político para corrigir falhas alocativas de direitos sociais para todos (educação, saúde etc.) é diferente de mobilizar meios de desbloquear politicamente um conjunto de instituições que subministram serviços de punição que afetam, desproporcionalmente, os setores mais pobres e marginalizados da sociedade. Ou seja, resolvido o problema da estrutura dos presídios, isso não significará o desaparecimento de outras violações a direitos fundamentais que não serão resolvidos após o “desbloqueio" político ${ }^{64}$.

${ }^{60}$ GUARNIZO, Diana; JARAMILLO, Juan Fernando; Uprimny, Rodrigo. Intervención judicial en las cárceles. Revista del Foro Constitucional Iberoamericano, n. 12, Octubre 2005 - Octubre 2006. p. 150.

${ }^{61}$ ARIZA, Libardo José. The Economic and Social Rights of Prisoners and Constitutional Court Intervention in the Penitentiary System in Colombia. In: MALDONADO, Daniel Bonilla. Constitutionalism of the Global South. The Activist Tribunals of India, South Africa and Colombia. New York: Cambridge University Press, 2013, p. 134. A eficácia da decisão na Colômbia e a divergência acadêmica sobre o ponto não pretendem ser utilizadas como argumentos de autoridade, mas, ao contrário, pontuar que o instituto não é uma unanimidade entre aqueles que pensam e debatem o sistema constitucional e político colombianos diuturnamente, na intenção de problematizarmos o otimismo ingênuo dos empréstimos constitucionais feitos pelo Direito Constitucional brasileiro. Sobre o otimismo metodológico dos brasileiros, cf. SILVA, Virgílio Afonso da. Interpretação constitucional e sincretismo metodológico. In: ___ (Org.). Interpretação constitucional. São Paulo: Malheiros, 2005. p. 115-143.

62 ARIZA, Libardo José. The Economic and Social Rights of Prisoners and Constitutional Court Intervention in the Penitentiary System in Colombia. In: MALDONADO, Daniel Bonilla. Constitutionalism of the Global South. The Activist Tribunals of India, South Africa and Colombia. New York: Cambridge University Press, 2013.

${ }^{63}$ Landau, analisando a jurisprudência da CCC sobre direitos sociais, conclui que os principais beneficiários diretos dos remédios determinados por aquela corte foram grupos de classe média e alta, e nenhuma abordagem ativa da Corte teve muito sucesso na alteração de uma política pública ou do comportamento burocrático do Estado, convertendo suas ações em maior benéfico para os pobres, muito embora considere que o $\mathrm{ECl}$ pode ser a tentativa de romper esse ciclo, ainda que sem sucesso no caso da saúde. LANDAU, David. The Reality of Social Rights Enforcement. Harvard International Law Journal, Vol. 53, Number 1, 2012. p. 401-459.

${ }^{64}$ ARIZA, Libardo José. The Economic and Social Rights of Prisoners and Constitutional Court Intervention in the Penitentiary System in Colombia. In: MALDONADO, Daniel Bonilla. Constitutionalism of the Global South. The Activist Tribunals of India, South Africa and Colombia. New York: Cambridge University Press, 2013. p. 152-156. 
A principal violação de direitos humanos dos encarcerados envolve sua liberdade e não, necessariamente, seus direitos sociais; portanto, respostas orçamentárias seriam insuficientes para saná-las. As violações não cessam com a construção de mais e melhores presídios, pois os presos que acessam as cortes ${ }^{65}$ para terem suas vozes ouvidas não pretendem que sejam mantidos, exatamente, onde estão. De acordo com o STF, os encarcerados devem arcar com os ônus da penalização de suas ações cometidas, supostamente, por livre-arbítrio e, ainda por cima, aguardar enquanto os poderes públicos se articulam para mantê-los afastados da sociedade, ainda que mais bem acomodados ${ }^{66}$.

$0 \mathrm{ECl}$ do STF, dessa forma, apenas repete os problemas socioculturais dos demais poderes, que creem na existência do "bom presídio" ${ }^{67}$, ou seja, insiste na crença de que a criação de condições de acolhimento dos encarcerados próximas das de um hotel 05 estrelas será uma via que extinguirá as violações de direitos fundamentais ocorridas nos estabelecimentos prisionais. Como exemplo mais próximo dessa ideologia subjacente na decisão do STF, basta indicar a ausência de efeitos práticos da MC na ADPF 347, em face das rebeliões nacionais do início do ano de $2017^{68}$; a preocupação da corte em descontingenciar os recursos do FUNPEN (demonstrando que o problema seria de alocação de recursos para a construção de mais presídios) e o discurso implícito da corte, passados quase quatro anos da decretação do $\mathrm{ECl}$ : “encarcerados, seus direitos fundamentais mais básicos estão sendo vilipendiados de maneira inaceitável por conta da atuação negligente do Estado brasileiro e sua dignidade está reduzida à pó dentro das cadeias de todo o Brasil, contudo, aguentem firmes em suas celas mais um pouco até decidirmos o mérito da ação".

Diante da falta de claridade e fluidez dos requisitos apresentados pelo STF, é provável que a corte utilize (se voltar a utilizar o $\mathrm{ECI}$ no futuro) o critério Stewart de obscenidade ${ }^{69}$ para

\footnotetext{
${ }^{65}$ No caso colombiano, não no Brasileiro. Discutirei mais sobre o ponto posteriormente.

${ }^{66}$ ARIZA, Libardo José. The Economic and Social Rights of Prisoners and Constitutional Court Intervention in the Penitentiary System in Colombia. In: MALDONADO, Daniel Bonilla. Constitutionalism of the Global South. The Activist Tribunals of India, South Africa and Colombia. New York: Cambridge University Press, 2013, p. 145-156.

${ }^{67}$ CHIES, Luiz Antônio Bogo. A questão penitenciária. Tempo Social, São Paulo, v. 25, n. 1, p. 15-36, jun. 2013, p. 33.

68 Disponível em: http://g1.globo.com/am/amazonas/noticia/2017/01/massacre-completa-uma-semanae-crise-carceraria-segue-no-amazonas.html e ttp://www1.folha.uol.com.br/cotidiano/2017/04/1873796seis-detentos-sao-mortos-em-presidio-de-manaus-seguranca-e-reforcada.shtml.

${ }^{69}$ A frase "Eu sei quando eu vejo" é uma expressão coloquial pela qual um falante tenta categorizar um fato ou evento observável, embora a categoria seja de catgorização subjetiva ou de parâmetros obscuros. A frase foi usada em 1964 pelo juiz da Suprema Corte dos Estados Unidos, Potter Stewart, para descrever seu teste para a obscenidade tolerada pela liberdade de expressão em Jacobellis v. Ohio.
} 
decretar um $\mathrm{ECl}$ : não se tenta demonstrar como se caracteriza de maneira clara e detalhada o $\mathrm{ECl}$, mas será possível reconhecer um quando visto.

No tocante aos requisitos ocultos do ECI no STF: sub-representação parlamentar e a impopularidade dos encarcerados, muito embora não tenham sido elencados como requisitos essenciais para a declaração do $\mathrm{ECl}$, a sub-representação parlamentar e a impopularidade dos encarcerados foram determinantes para sua decretação no Brasil, e são exatamente esses dois elementos que tornarão o instituto uma doutrina de um caso só, não obstante a fluidez e obscuridade dos requisitos anteriores permitirem seu cabimento em inúmeras oportunidades.

Alerta-se antecipadamente o leitor que nessa seção sustenta-se dois argumentos distintos, embora relacionados: $1^{\circ}$ ) a limitação do cabimento do $\mathrm{ECl}$ no Brasil a um único caso, ao sugerir que, em verdade, seu cabimento dependerá da sub-representação parlamentar do grupo envolvido e da impopularidade da demanda na política, requisitos, tal como dispostos pelo próprio STF, observados apenas no caso dos encarcerados e $2^{\circ}$ ) não obstante o tribunal ter elencados aqueles requisitos implícitos como os reais viabilizadores de um $\mathrm{ECl}$, eles não são consistentes ou coerentes.

O Brasil é um país em desenvolvimento, mas por fazer parte do sul-global, compartilha de muitos de seus problemas: pobreza, insegurança, níveis preocupantes de desigualdade, violência policial, corrupção, conflitos de terras etc. Todos esses problemas foram captados pela Constituinte de $87 / 88$, que aspirava, por meio do constitucionalismo, transformar socialmente 0 Brasil.

A manutenção ou agravamento desse quadro de violações às normas constitucionais de cunho transformador ${ }^{70}$ representa um descompasso entre as aspirações políticas e a realidade brasileira. E nada mais simples do que comprovar o cumprimento dos três requisitos elencados pelo STF para declarar um ECl total nos casos da saúde, educação, moradia, alimentação, segurança pública, liberdade de imprensa, proteção de grupos vulneráveis, direitos de povos tradicionais etc. Não apenas porque, como se mostrou nas seções anteriores, o STF não construiu requisitos claros, permitindo a identificação de um $\mathrm{ECl}$ ainda que por meio de uma frágil argumentação jurídica, mas, principalmente, porque ainda persiste, faticamente, uma violação generalizada daqueles direitos fundamentais ocasionada por uma omissão/inércia/incapacidade dos três poderes e uma ação conjunta deles poderá saná-la.

\footnotetext{
${ }^{70}$ Art. 3 I- construir uma sociedade livre, justa e solidária; II - garantir o desenvolvimento nacional; III erradicar a pobreza e a marginalização e reduzir as desigualdades sociais e regionais. BRASIL. Constituição Federal. Brasília: Senado Federal, $1988 . \quad$ Disponível em:
} http://www.planalto.gov.br/ccivil_03/Constituicao/Constituiçao.htm. Acesso em: 9 jun 2017. 
Contudo, Marco Aurélio se antecipou à crítica e jogou uma pá de cal nas esperanças dos entusiastas das criações vazias do STF, sustentando que nosso crônico problema sanitário não justificaria a declaração de um $\mathrm{ECl}$, por exemplo. 0 motivo? A evidente vontade política em solucionar o caos na saúde pública e a sensibilidade social quanto ao tema. Ou seja, não obstante a violação da dignidade humana de forma generalizada, os programas sociais, ineficientes e a intervenção desajeitada do Judiciário no tema, o simples fato de o Direito à Saúde figurar como bandeira político-partidária e estar na pauta de preocupações do brasileiro médio $^{71}$ tem o condão de afastar os pressupostos de cabimento do $\mathrm{ECl}$, ou seja, ambos são requisitos prejudiciais implícitos.

Com efeito, não seriam apenas três os requisitos para a decretação de um $\mathrm{ECl}$, mas cinco: 1) situação de violação generalizada de direitos fundamentais; 2) inércia ou incapacidade reiterada e persistente das autoridades públicas em modificar a situação identificada, 3) que a superação das transgressões exija a atuação de todas as autoridades políticas; 4) Subrepresentação parlamentar da população atingida pela violação generalizada e a 5) a impopularidade social dos atingidos pelas violações. Os dois últimos requisitos podem ser substituídos, como alternativa, pela fórmula "existência de bloqueio político"72, sugerida mais acima. Em seguida, criticaremos aqueles dois últimos requisitos implícitos.

Para o STF, a sub-representação parlamentar decorre do fato de os encarcerados ficarem impedidos de votar e serem votados (suspensão dos direitos políticos), não gozando de representação política direta no Congresso.

0 argumento do Ministro é problemático pelas seguintes razões: a) não são apenas os encarcerados que são sub-representados no Congresso, mas, também, as camadas mais pobres da sociedade, as mulheres, os negros, os povos tradicionais, a comunidade LGBTI, ou seja, a subrepresentação é uma característica do Poder Legislativo brasileiro e não uma exclusividade dos encarcerados e b) ainda que o item anterior seja aceito como verdadeiro, para fins argumentativos, a ausência de representantes políticos dos encarcerados nos assentos da

71 O ministro não apresentou nenhuma pesquisa científica para reforçar sua conclusão, reforçando a natureza especulativa e intuitiva de sua afirmação.

72 Novamente, o Min. Marco Aurélio: "No caso dos presos, os bloqueios ou desacordos políticos encontram razões tanto na sub-representação parlamentar como na impopularidade desses indivíduos" (...) "É difícil imaginar candidatos que tenham como bandeira de campanha a defesa da dignidade dos presos. A rejeição popular faz com que a matéria relativa à melhoria do sistema prisional enfrente o que os cientistas políticos chamam de 'ponto cego legislativo' (legislative blindspot): o debate parlamentar não a alcança”. (...) "Em síntese, a impopularidade dos presos faz com que os políticos, salvo raríssimas exceções, não reivindiquem recursos públicos a serem aplicados em um sistema carcerário voltado ao oferecimento de condições de existência digna" e "Essa rejeição tem como consequência direta bloqueios políticos, que permanecerão se não houver intervenção judicial” 
Câmara ou do Senado significaria que, para fins de uma adequada representação popular no Congresso devam constar representantes de todas as categorias sociais e profissionais para que os seus direitos e interesses sejam garantidos de maneira efetiva? Ou seja, apenas padeiros defenderão interesses de padeiros, apenas empregadas domésticas poderão defender interesses de empregadas domésticas etc ${ }^{73}$. Se levarmos essa argumentação de sub-representação política temática do STF ao extremo, talvez pudéssemos concluir que a atual legislatura é inconstitucional, ainda que composta por membros eleitos pelo povo, por não dar assento a todo espectro profissional e social de brasileiros. Portanto, em todos e quaisquer casos de políticas públicas (saúde, alimentação, moradia, imprensa etc), seguindo o critério do STF, será possível sustentar a sub-representação parlamentar.

O segundo requisito implícito é a impopularidade dos presos, descritos pelo relator como “minoria socialmente desprezada". O artigo científico citado pelo Ministro como referência para o tópico ${ }^{74}$ talvez não tenha sido a melhor opção para provar seu argumento no ponto, sobre a impopularidade da população carcerária, bem como a respeito de seu argumento mais amplo sobre o $\mathrm{ECl}^{75}$.

A autora do artigo citado não conduziu pesquisa empírica para sustentar a hipótese absorvida pelo relator da ADPF 347 acerca da percepção dos cidadãos não encarcerados de que o criminoso não deve ser titular de direitos fundamentais ${ }^{76}$. Ainda que tenha mencionado, na nota

\footnotetext{
${ }^{73}$ Waldron (348-350), por exemplo, considera que a representação com base em critérios mais genéricos e abstratos (representação geográfica, federal, estadual etc) são melhores para o debate e construção de argumentos dentro do contexto de criação de leis, ou seja, representação abstrata é mais desejável, do ponto de vista da teoria política, do que representantes designados para defender um interesse especifico de uma classe social ou profissional. O mais importante é a representação dos interesses, não das pessoas cujo interesse esteja em debate. A presença no congresso deve ser do tipo de interesse, e não da manifestação pessoal do interesse. O STF parece entender representação política de outra forma para o $\mathrm{ECl}$, ou seja, para o cabimento do $\mathrm{ECl}$ precisamos averiguar se há no Congresso Nacional Deputados e Senadores que representem uma bandeira, sendo preferencial que esses congressistas façam parte da categoria social ou profissional para a qual hasteiam sua bandeira política.

${ }^{74}$ BARCELLOS, Ana Paula de. Violência urbana, condições das prisões e dignidade humana. Revista de Direito Administrativo $\mathrm{n}^{\circ} 254,2010$.

75 Seguem algumas conclusões de Barcellos: 1) a questão carcerária não é estranha à proteção internacional de direitos humanos ratificada pelo Brasil, porquanto o Estado internalizou as principais normas e tratados internacionais; 2) não é possível defender uma omissão legislativa e constitucional sobre os direitos dos presos - a autora reconhece, inclusive, a vanguarda da produção legislativa brasileira sobre seus direitos; 3 ) a causa central do problema não é a falta de recursos, especialmente após a criação do FUNPEN e 4) o artigo não reputa as ações do Judiciário, Ministério Público e Defensoria Pública como omissas ou indiferentes ao tema do sistema prisional. BARCELLOS, Ana Paula de. Violência urbana, condições das prisões e dignidade humana. Revista de Direito Administrativo n 254, 2010. p. 47, 48, 51 e 55.

76 "Conforme apontou Ana Paula de Barcellos, os cidadãos livres acreditam, recusando a dimensão ontológica da dignidade humana, que o criminoso perde o direito à vida digna ou mesmo a condição humana, não sendo titular de quaisquer direitos fundamentais"
} 
de rodapé 41 , que saúde, segurança pública e educação compunham o conjunto das maiores preocupações dos eleitores no pleito presidencial de 2010, a autora não correlaciona a pesquisa àquele argumento sobre direitos fundamentais dos presos, e nem poderia, tendo em vista que a pesquisa referida não perguntou aos entrevistados sua opinião direta sobre a titularidade dos direitos fundamentais dos encarcerados, mas sim quais eram as principais preocupações dos eleitores para o pleito presidencial daquele ano.

O Ministro não problematizou o fato de a violência figurar como uma das principais preocupações do brasileiro nas eleições de 2014 (64 \%), além de os brasileiros considerarem os combates à violência e à criminalidade como prioridades que deveriam ser atendidas no $2^{\circ}$ mandato Dilma (29 \%) ${ }^{77}$. Para as eleições de 2018, $15 \%$ dos brasileiros consideraram que violência deveria ser uma área de preocupação do Presidente da República ${ }^{78}$.

A população carcerária brasileira ultrapassa as 600.000 mil pessoas ${ }^{79}$, cada uma dessas pessoas possui familiares que podem estar preocupados com as condições de encarceramento de seu ente querido, perfazendo uma cifra de quase um milhão de pessoas com essas espécies de preocupações no momento de comparecerem às urnas ${ }^{80}$.

Não há uma correlação direta entre o estabelecimento de prioridades eleitorais e a percepção comum da sociedade acerca dos direitos fundamentais dos presos, um dado que, ademais, não poderia ser inferido das pesquisas de cunho eleitoral conduzidas pelo IBOPE e citadas por Barcellos e Marco Aurélio (ADPF 347).

Por fim, Marco Aurélio sugere que a opinião pública, refratária às mazelas da população carcerária, constrange negativamente os políticos a aplicarem e defenderem prioridades nos gastos públicos nessas áreas, temerosos de não serem recompensados com a reeleição. Novamente, o ministro constrói uma hipótese que não pode ser confirmada sem pesquisa empírica. Rápida análise, porém, feita nos projetos de governo dos candidatos à presidência de 2014 demonstra que os dois principais candidatos, Dilma Rousseff e Aécio Neves, apresentaram propostas concretas para lidar com o problema prisional.

Em seu programa, a candidata Dilma considerou que o "sistema prisional brasileiro está entre as prioridades na área de segurança pública". Ademais, "O Programa de Apoio ao Sistema

77 Disponível em http://www.ibopeinteligencia.com/arquivos/antigos/RSB\%2022\%20\%20Problemas\%20e\%20prioridades.pdf. Acesso em 05 set 2017.

78 Disponível em https://g1.globo.com/politica/eleicoes/2018/eleicao-emnumeros/noticia/2018/09/11/saude-e-violencia-sao-os-principais-problemas-para-os-eleitores-brasileirossegundo-datafolha.ghtml. Acesso em 23 jul 2019.

79 Disponível em http://www.cnj.jus.br/noticias/cnj/84371-levantamento-dos-presos-provisorios-do-paise-plano-de-acao-dos-tribunais. 654.372 mil presos, para sermos mais exatos, de acordo com dados do CNJ. $80 \mathrm{O}$ argumento foi formulado e sugerido por Diego Werneck Arguelhes. 
Prisional destinou, no primeiro governo Dilma, R\$ 1,1 bilhão para que os Estados pudessem ampliar e construir unidades prisionais, gerando 47.419 novas vagas" ${ }^{81}$. Por outro lado, Aécio Neves ${ }^{82}$, afirma que "o Problema Prisional, que se tornou, hoje, um dos mais graves problemas de segurança pública”. Reforçou, também, que “...Para que tudo isto seja possível, iremos assegurar um fluxo contínuo e estável de financiamentos para estados e municípios através de diferentes fundos, sem contingenciamento e buscaremos proporcionar apoio técnico e administrativo" 83 . Não parece prosperar, igualmente, o requisito da impopularidade temática.

Isso vale também, mais recentemente, para os dois candidatos que foram para o $2^{\circ}$ turno nas eleições presidenciais de 2018. O candidato derrotado, Fernando Haddad, sugeriu a criação de um Plano Nacional de Política Criminal e Penitenciária, o qual visava a responsabilização dos criminosos, aplicando penas proporcionais aos crimes cometidos, combatendo a impunidade. 0 Plano, ademais, previa ações para o fortalecimento do sistema nacional de gestão penitenciária e a criação de uma Escola Penitenciária Nacional para capacitação de gestores do Sistema. Por fim, especificamente sobre o encarceramento, o presidenciável propunha a diminuição da pressão sobre o sistema carcerário, trazendo ganhos globais de economia de recursos abrindo espaço para que as polícias civil e militar se concentrem na repressão a crimes violentos, com foco na redução de homicídios e para evitar roubos e furtos ${ }^{84}$.

0 atual Presidente da República, Jair Bolsonaro, dedicou espaço em seu plano de governo para tratar da questão carcerária, dando indícios de como uma política pública sobre o tema deve ser encarada: “Prender e deixar na Cadeia Salva Vidas!”. Entre as propostas do presidente, podemos destacar as seguintes: a) acabar com a progressão de penas e as saídas temporárias; b)

${ }^{81}$ ROUSSEFF, Dilma. Mais Mudanças, Mais Futuro: Programa de Governo, 2014. p. 23.

82 NEVES, Aécio. Diretrizes Gerais Plano de Governo - PSDB, 2014. p. 64-65.

${ }^{83} \mathrm{O}$ candidato do PSDB listou, ainda, as seguintes linhas de atuação, especificamente, sobre o tópico: 4. Apoio a projetos de educação e formação profissional em tempo integral nas áreas de maior vulnerabilidade em relação à segurança. 5 . Articulação e integração das políticas de segurança pública com o Sistema Único de Assistência Social - SUAS, para atendimento de famílias residentes nas áreas vulneráveis. 11. Proposição de um conjunto de medidas legislativas, sugeridas por grupos de juristas de excelência, visando a qualificação dos diversos projetos relativos à Lei Processual Penal e à Lei de Execução Penal, em tramitação no Congresso Nacional, para combater a impunidade. 21. Ampliação e desenvolvimento de sistemas de informações gerenciais adequados para a população prisional, permitindo separar presos de menor periculosidade, que podem cumprir penas alternativas ou utilizar tornozeleiras ou pulseiras eletrônicas, bem como identificar aqueles que efetivamente já cumpriram suas penas. 22. Ampliação das prisões federais, de forma a abrigar especialmente as lideranças do crime organizado. 23. Apoio aos programas de cumprimento de penas alternativas, bem como o apoio à adoção de instrumentos de vigilância eletrônica de apenados.

84 HADDAD, Fernando. PLANO DE GOVERNO 2019-2022: PT, 2018. p. 33. 
redução da maioridade penal para 16 anos e c) reformulação do Estatuto do Desarmamento para garantir o direito, de acordo com o presidente, à legítima defesa ${ }^{85}$.

A inserção do $\mathrm{ECl}$ no direito constitucional brasileiro, especialmente como um capítulo especial da omissão constitucional, de acordo com Carlos Campos, cria a categoria de violações generalizadas de direitos fundamentais constitucionalmente toleráveis, pois os políticos poderão argumentar que estão empregando esforços para solucioná-las, ao que o STF irá afastar de sua jurisdição os principais problemas brasileiros do alcance do $\mathrm{ECl}$, exatamente aqueles que estão no topo das preocupações dos eleitores.

No julgamento da ADO 1968, proposta em 1997, por partidos de esquerda (PT, PDT e PC do B) durante o governo da oposição (PSDB), os autores questionavam dados do IBGE (1995) que demonstravam a manutenção do analfabetismo no Brasil, e alegavam a omissão do Executivo no cumprimento do arts. $6^{\circ}, 23, \mathrm{~V}, 208$, I, e 214, I. Para declarar a improcedência da ação, a Ministra relatora, Cármen Lúcia, afastou a omissão executiva ao justificar a apresentação de um Projeto de Lei (1258-B), posteriormente convertido na lei 9.394/96 (Lei de Diretrizes e Bases da Educação Nacional) e a edição da lei 10.172/01, que estabeleceu o plano nacional da educação, e a política social intitulada como "Programa Brasil Alfabetizado".

Por fim, ao notar que o novo recenseamento do IBGE feito em 2000 apontou a redução do analfabetismo no Brasil de 32, para 14, 6 milhões, a relatora ponderou que "embora não seja o número com o qual o País possa conviver sem adoção de drásticas medidas para extirpar tão grave mal, dando pleno cumprimento à Constituição, demonstra a atuação do Poder Público na reversão dos dados apresentados (...)". Após ressaltar o atraso brasileiro em erradicar o analfabetismo, quando comparado a outros Estados mais pobres da América Latina, a relatora concluiu afirmando "que o Brasil tem muitíssimo a fazer em termos de compromisso constitucionalmente imposto de erradicar o analfabetismo, até mesmo para que os direitos fundamentais, a dignidade da pessoa humana, a sua liberdade, a igualdade de oportunidades possam ser efetivados" $"$.

O tribunal, no caso ora em análise, afastou a inércia do Executivo, muito embora tenha reconhecido a violação do direito fundamental de, pelo menos, 14 milhões de brasileiros em função das medidas legislativas e administrativas empreendidas pelo Executivo. Isso não quer dizer que o tribunal tenha cruzado os braços para a chaga do analfabetismo, mas constatou a

85 BOLSONARO, Jair. O CAMINHO DA PROSPERIDADE: Proposta de Plano de Governo: PSL, 2018. p. 32.

86 Importante ressaltar que o Ministro Marco Aurélio, além de sindicar a possibilidade de controle de constitucionalidade por omissão de políticas públicas, considerou que o Poder Público é inerte no tocante à Educação, alertando para os efeitos indiretos da improcedência da ação (constatação de que o máximo está sendo feito para erradicar o analfabetismo). 
progressiva implementação e concretização desse direito social - a "vontade política" ficou demonstrada por meio de um projeto de lei e de uma política pública do Executivo. Dessa forma, o campo de aplicação do $\mathrm{ECl}$ no Brasil ficará restrito ao caso do sistema carcerário, por ser o único, na leitura feita pelo tribunal, que cumpre com os requisitos da sub-representação política e impopularidade temática.

Com efeito, no caso dos presídios, o STF teve de fundamentar a decretação do $\mathrm{ECI}$ no Brasil com base em dois requisitos não elencados em sua formulação original (sub-representação política e impopularidade social e temática) para afastar sua aplicação descontrolada em um país cujos problemas estruturais seriam facilmente capturados pelos três requisitos explícitos do $\mathrm{ECI}$. Dessa forma, o STF precisou escamotear aqueles dois requisitos para dar a impressão de que a doutrina seria aplicada, dogmaticamente, de forma genérica para outras hipóteses. Os requisitos escamoteados, porém, não apenas restringem a incidência artificial do $\mathrm{ECl}$ ao caso dos presídios, mas, além disso, eles foram desenvolvidos pelo STF de forma incoerente e de difícil reprodução em outros casos.

Se, de acordo com o raciocínio da corte, eu preciso de uma violação sistemática de direitos fundamentais que decorra de omissão conjunta dos três poderes ocasionada por bloqueios políticos para um $\mathrm{ECl}$, não conseguimos pensar em outro tema no Brasil que possa se encaixar nesses mal formulados termos criados pelo STF. Educação, saúde, segurança pública, economia, redução das desigualdades regionais, racismo, fome, falta de moradia etc, todos são temas que não apresentam o "bloqueio político" que, supostamente, só poderá ser rompido pelo aríete manejado e de propriedade exclusiva de nossa suprema corte.

\section{CONCLUSÃO}

Do ponto de vista dogmático, não é tarefa simples explicar a inserção do $\mathrm{ECl}$ no direito constitucional brasileiro. A decisão do STF na ADPF 347 é inconsistente na caracterização dos pressupostos que justificariam a declaração de um ECl no Brasil, as cautelares deferidas são inócuas, há uma injustificada demora no julgamento do mérito, os poderes apresentaram respostas tacanhas e que seguem a mesma natureza das políticas tradicionalmente desenvolvidas no Brasil e a capacidade de uma corte suprema mudar um estado fático de coisas por meio do direito é posta em dúvida. 
O aparente ceticismo das conclusões não pretende defender a manutenção do status quo da população carcerária no Brasil, contudo, chegou a hora de abandonarmos alguns traços de nossa teoria constitucional, para que possamos desenvolver doutrinas mais arrojadas e mais efetivas para a proteção dos direitos fundamentais.

O empréstimo constitucional irrefletido estimula a utilização de doutrinas ou teses gestadas em outros países, mas impede o desenvolvimento de seus contornos dogmáticos, no sentido de justifica-la e reproduzi-la. 0 otimismo metodológico, que, em verdade, esconde o viés de confirmação da tese defendida, e é incapaz de fornecer informações capazes de descrever ou explicar o direito constitucional brasileiro precisa terminar.

A incorporação jurisprudencial de teorias pouco desenvolvidas ou equivocadas (diálogos institucionais, capacidades institucionais, função pedagógica das cortes, litígio de interesse público etc.) demonstram uma preocupante confusão entre o papel da ciência do direito e sua prática, especialmente quando o STF "adota" uma "teoria" criada para explicar uma realidade constitucional estrangeira para justificar decisões que parecem extrapolar suas competências constitucionais, além de não fornecer indícios para a formulação de uma dogmática capaz de compreender o instituto incorporado.

\section{REFERÊNCIAS}

AMANCIA, Natália Alves. O princípio da dignidade da pessoa humana na jurisprudência do STF. 2010. Monografia (Aperfeiçoamento/Especialização em Escola de Formação) - Sociedade Brasileira de Direito Público.

ANDRADE, Bruno Araújo de; TEIXEIRA, Maria Cristina. O Estado de Coisas Inconstitucional - Uma Análise da ADPF 347. In: Revista do Curso de Direito da Faculdade de Humanidades e ireito, v. 13, n. 13, 2016, p. 85-121.

ARGULHES, Diego Werneck; LEAL, Fernando. 0 argumento das 'capacidades institucionais' entre a banalidade, a redundância e o absurdo. In: Direito, Estado e Sociedade, v. 38, p. 6-50, 2014.

ARIZA, Libardo José. The Economic and Social Rights of Prisoners and Constitutional Court Intervention in the Penitentiary System in Colombia. In: MALDONADO, Daniel Bonilla. Constitutionalism of the Global South. The Activist Tribunals of India, South Africa and Colombia. New York: Cambridge University Press, 2013, p. 129-159.

BARCELLOS, Ana Paula de. Violência urbana, condições das prisões e dignidade humana. In: Revista de Direito Administrativo $\mathrm{n}^{\circ} 254$, 2010, p. 39-65.

BETANCUR HINCAPIE, Guillermo Leon. Activismo de la Corte Constitucional ColombianaArgumentos que lo justifican. In: Nuevo Derecho, v.10, ano 14, p. 09 - 20, 2014. 
BERNARDI, Renato; MEDA, Ana Paula. Da Tripartição de Poderes ao Estado de Coisas Inconstitucional e o Compromisso Significativo: A contemporânea atuação do Poder Judiciário na solução de conflitos que envolvem direitos sociais fundamentais. In: EM TEMPO, vol. 15, p. 1134, 2016.

BUSTAMANTE, Gabriel. Estado de cosas inconstitucional y políticas públicas. Dissertação (Mestrado em Estudos Políticos) - Pontificia Universidad Javeriana, Colômbia, Bogotá, 2011.

BRASIL. Constituição Federal. Brasília: Senado Federal, 1988. Disponível em: http://www.planalto.gov.br/ccivil_03/Constituicao/Constituiçao.htm. Acesso em: 9 jun. 2017

BRASIL. Supremo Tribunal Federal. Medida Cautelar na ADPF 347. ADPF $n^{\circ}$ 347. PARTIDO SOCIALISMO E LIBERDADE. Relator: Ministro Marco Aurélio. 09 de Setembro de 2015. Disponível em: <http://redir.stf.jus.br/paginadorpub/paginador.jsp?docTP=TP\&doclD=10300665>. Acesso em: 18 de Setembro de 2017.

CAMPOS, Carlos Alexandre de Azevedo. Estado de Coisas Inconstitucional. Salvador: Juspodivm, 2016.

CAMPOS, Carlos Alexandre de Azevedo. Jota Mundo: Estado de Coisas Inconstitucional. Artigo publicado in: http://jota.info/jotamundo-estado-de-coisas-inconstitucional. Acesso em 03 set 2017.

CALDAS, Roberto Correia da Silva Gomes; NETO, Felipe Lascane. As condições das penitenciárias no brasil e o estado de coisas inconstitucional. In: Revista de Direito Penal, Processo Penal e Constituição v. 2, n. 2, p. 578 - 600, 2016.

CARVALHO, Gustavo Ferreira de; OLIVEIRA, Fábio de Souza, SANTOS, Júlio Edstron S. O estado de coisas inconstitucional: é possível sua efetivação no Brasil? In: Revista Acadêmica Conecta FASF. Vol. 2, n 1, p.307-332, 2017.

CEPEDA-ESPINOSA, Manuel José. Judicial Activism in a Violent Context: The Origin, Role, and Impact of the Colombian Constitutional Court. In: Washington University Global Studies Law Review, Vol. 3, 2004, pp. 529/691.

CHIES, Luiz Antônio Bogo. A questão penitenciária. In: Tempo Social, São Paulo, v. 25, n. 1, p. 15-36, jun. 2013.

DANTAS, Eduardo Sousa. Ações estruturais, direitos fundamentais e o estado de coisas inconstitucional. In: Revista constituição e garantia de direitos. Vol. 09, n. 02, 2016, p. 155176.

DE GIORGI, Raffaele; FARIA, José Eduardo; CAMPILONGO, Celso. Estado de Coisas Inconstitucional. Artigo publicado in: Estadão em 19.09.2015. Disponível em: http://opiniao.estadao.com.br/estado-de-coisas-inconstitucional. Acesso em 01 set 2017.

DUARTE, Júlia Karolline Vieira; NETO, Júlio Gomes Duarte. O estado de coisas inconstitucional (ECI): o remédio estrutural para a efetivação dos direitos fundamentais perante um diálogo entre os poderes da união. In: Revista da ESMAL, n.1, p. 298-321, 2016. 
FISHER, Louis; DEVINS, Neal. The Democratic Constitution. New York: Oxford University Press, 2004.

FISHER, Louis. Constitutional Dialogues: interpretation as political process. Princeton: Princeton University Press, 1988.

FERREIRA, Carolina Cutrupi; MACHADO, Maíra Rocha. Exclusão social como prestação do sistema de justiça: um retrato da produção legislativa atenta ao problema carcerário no Brasil. In: RODRIGUEZ, José Rodrigo. (Org.). In: Pensar o Brasil: Problemas nacionais à luz do direito. São Paulo: Saraiva, 2012, p. 77-107.

GARCIA, L. S. Reflexões sobre o instituto da intervenção federal e a questão do sistema prisional brasileiro. In: Aracê: Direitos Humanos em Revista, v. 1, p. 4-207, 2014.

GUARNIZO, Diana; JARAMILLO, Juan Fernando; Uprimny, Rodrigo. Intervención judicial en las cárceles. In: Revista del Foro Constitucional Iberoamericano, n. 12, Octubre 2005 - Octubre 2006, pp. 129-163.

GLEZER, Rubens; MACHADO, Eloísa. Decide, mas não muda: STF e o Estado de Coisas Inconstitucional [online]. In: JOTA. Publicado em 9 de setembro de 2015. Disponível em: https://goo.gl/Xck1iL. Acesso em 24 set. 2017.

LANDAU, David. The Reality of Social Rights Enforcement. In: Harvard International Law Journal, Vol. 53, Number 1, 2012, p. 401-459.

LEAL, Fernando; ARGUELHES, Diego Werneck. Dois problemas de operacionalização do argumento das 'Capacidades Institucionais'. In: Revista de Estudos Institucionais , v. 2, p. 192213, 2016.

MAGALHÃES, Breno Baía. O Estado de Coisas Inconstitucional na ADPF 347 e a sedução do Direito: o impacto da medida cautelar e a resposta dos poderes políticos. In: REVISTA DIREITO GV (ONLINE), v. 15, p. 1-37, 2019.

MEDA, Ana Paula; BERNARDI, Renato. Direito Fundamental à Moradia e a Sentença T-025/2004 da Corte Constitucional da Colômbia: Estado de Coisas Inconstitucional no Brasil. In: Revista de Direito Sociais e Políticas Públicas, v. 2, n. 1, p. 280-299, 2016.

MEDINA QUIROGA, Cecilia. Los 40 años de la Convención Americana sobre Derechos Humanos a la luz de cierta jurisprudencia de la Corte Interamericana. In: Anuario de derechos humanos, $\mathrm{n}^{\circ}$ 05, Santiago, p. 15-34, 2009.

NEVES, Aécio. Diretrizes Gerais Plano de Governo - PSDB, 2014.

OLIVEIRA, Vitor Costa. Estado de coisas inconstitucional no direito fundamental à comunicação: análise do regime jurídico da radiodifusão audiovisual no Brasil. 2016. 121 f. Dissertação (Pós-Graduação em Direito) - Universidade Federal de Sergipe, São Cristóvão, 2016. 
PENNA, Bernardo Schmidt. Mais do ativismo judicial à brasileira: análise do estado de coisas inconstitucional e da decisão na ADPF 347. In: Revista Pensamento Jurídico. Vol. 11, $\mathrm{n}^{\circ} 1$, 2017, p. 09-19.

PEREIRA, Luciano Meneguetti. O Estado de Coisas Inconstitucional e a violação dos direitos humanos no sistema prisional brasileiro. In: RIDH, v. 5, n. 1, p. 167-190, 2017.

PICKERILL, J. Mitchell. Constitutional Deliberation in Congress: the Impact of Judicial Review in a Separated System. Durham: Duke University Press, 2004.

RODRÍGUEZ-GARAVITO, César. Beyond the courtroom: the impact of judicial activism on socioeconomic rights in Latin America. In: Texas Law Review, $\mathrm{n}^{\circ}$ 89, 2011, p. 1669-1698.

RODRÍGUEZ-GARAVITO, César. ¿Cuándo cesa el estado de cosas inconstitucional del desplazamiento? Más allá del desplazamiento, o cómo superar un estado de cosas inconstitucional. In: Más allá del desplazamiento: políticas, derechos y superación del desplazamiento forzado en Colombia. coordinador César Rodríguez Garavito; Juan Carlos Guataquí. et al. Bogotá: Universidad de los Andes, Facultad de Derecho, Ediciones Uniandes, 2009, p. 434-494.

RODRIGUEZ, José Rodrigo. Estado de coisas surreal. Disponível em: https://jota.info/artigos/estado-de-coisas-surreal-25092015. Acesso em 26 set 2017.

RODRIGUEZ, J. R. Dogmática é conflito: a racionalidade jurídica entre sistema e problema. In: José Rodrigo Rodriguez; Flávia Portella Püschel, Marta Rodriguez Assis Machado. (Org.). Dogmática é conflito: uma visão crítica da racionalidade jurídica. 1ed.São Paulo: Saraiva, 2012, p. 21-32.

RODRIGUEZ, J. R.; PÜSCHEL, F. P.; MACHADO, M. R. A. O raciocínio jurídico-dogmático e suas relações com o funcionamento do Poder Judiciário e a democracia. In: José Rodrigo Rodriguez; Flávia Portella Püschel, Marta Rodriguez Assis Machado. (Org.). Dogmática é conflito: uma visão crítica da racionalidade jurídica. 1ed. São Paulo: Saraiva, 2012, p. 33-54.

ROMERO PÁEZ, Nicolás Augusto. La doctrina del estado de cosas inconstitucional en Colombia novedades del neoconstitucionalismo y "la inconstitucionalidad de la realidad". In: Revista Derecho Público Iberoamericano, №. 1, 2012, p. 243-264.

ROUSSEFF, Dilma. Mais Mudanças, Mais Futuro: Programa de Governo, 2014.

SANTOS et. al. Estado de Coisas Inconstitucional: Um Estudo Sobre os Casos Colombiano e Brasileiro. In: Quaestio luris, vol. 08, nº. 04, 2015, p. 2.596-2.612.

SILVA, Virgílio Afonso da. Deciding without deliberating. In: International Journal of Constitutional Law. Vol. 11, nº 03, p. 557-584, 2013.

SILVA, Virgílio Afonso da. Direitos fundamentais: conteúdo essencial, restrições e eficácia. São Paulo: Malheiros, 2009.

SILVA, Virgílio Afonso da. Interpretação constitucional e sincretismo metodológico. In: SILVA, Virgílio Afonso da. (Org.). Interpretação constitucional. São Paulo: Malheiros, 2005, p. 115-143. 
STRECK, Lenio Luiz. Estado de coisas inconstitucional é uma nova forma de ativismo [online]. In: Revista Consultor Jurídico, 24 de outubro de 2015. Disponível em: https://goo.gl/ jkOALM. Acesso em 24 set 2017.

SUELT COCK, Vanessa. El estado de cosas de inconstitucionalidade. In: 20 Años de la Constitución Colombiana: logros, retrocesos y agenda pendiente. INÉS ACOSTA, Juana -López. et al (eds.). Bogotá: Fundación Konrad Adenauer, 2012, p. 203-223.

SUNSTEIN, Cass; VERMEULE, Adrian. Interpretation and Institutions. In: Michigan Law Review, vol. 101, pp. 885-951, 2003.

TILLER, Emerson H.; CROSS, Frank B. What is legal doctrine? In: Northwestern University Law Review, v.100, n.1, p. 517-533, 2006.

UPRIMNY, Rodrigo. Judicialization of Politics in Colombia: Cases, Merits and Risks. In: Sur International Journal on Human Rights, Vol. 6, 2007, p. 49-66.

WALDRON, Jeremy. Representative Lawmaking. In: Boston University Law Review. Vol. 89, 2009, p. 335-355.

WHITTINGTON, Keith E. Constitutional Construction: Divided Powers and Constitutional Meaning. Cambridge: Harvard University Press, 1999.

Recebido em: 26.05.2018 / Revisões requeridas em: 20.07.2019 / Aprovado em: 16.08.2019 / Publicado em: 14.09.2019

\section{COMO FAZER REFERÊNCIA AO ARTIGO (ABNT):}

MAGALHÃES, Breno Baía. A incrível doutrina de um caso só: análise do estado de coisas inconstitucional na ADPF 347. Revista Eletrônica do Curso de Direito da UFSM, Santa Maria, RS, v. 14, n. 3, e32760, set./dez. 2019. ISSN 1981-3694. DOI: http://dx.doi.org/10.5902/1981369432760. Disponível em:

https: //periodicos.ufsm.br/revistadireito/article/view/32760 Acesso em: dia mês. ano.

Direitos autorais 2019 Revista Eletrônica do Curso de Direito da UFSM

Editores responsáveis: Rafael Santos de Oliveira e Angela Araujo da Silveira Espindola

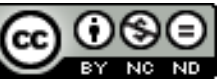

Esta obra está licenciada com uma Licença Creative Commons Atribuição-NãoComercial-SemDerivações 4.0 Internacional.

\section{SOBRE O AUTOR}

\section{BRENO BAÍA MAGALHÃES}

Possui graduação (2008), mestrado (2011) e doutorado (2015) em Direito pela Universidade Federal do Pará (UFPA). Foi Visiting Scholar na Washington College of Law, American University. Professor da Universidade Federal do Pará (UFPA). Menção Honrosa no Prêmio CAPES de Tese 2016. Suas principais áreas de atuação são: Direito Constitucional, Direito Internacional, Direitos Humanos e Teoria do Direito. Advogado. 